University of Nebraska - Lincoln

DigitalCommons@University of Nebraska - Lincoln

Reconstructing sea-level change from the internal architecture of stromatolite reefs: an example from the Mesoproterozoic Sulky Formation, Dismal Lakes Group, arctic Canada

\author{
L C. Kah \\ University of Tennessee - Knoxville, Ickah@utk.edu \\ Julie K. Bartley \\ University of West Georgia, \\ Tracy D. Frank \\ University of Nebraska-Lincoln, tfrank2@unl.edu \\ Timothy W. Lyons \\ University of California, Riverside, timothy.lyons@ucr.edu
}

Follow this and additional works at: https://digitalcommons.unl.edu/geosciencefacpub

Part of the Earth Sciences Commons

Kah, L C.; Bartley, Julie K.; Frank, Tracy D.; and Lyons, Timothy W., "Reconstructing sea-level change from the internal architecture of stromatolite reefs: an example from the Mesoproterozoic Sulky Formation, Dismal Lakes Group, arctic Canada" (2006). Papers in the Earth and Atmospheric Sciences. 100. https://digitalcommons.unl.edu/geosciencefacpub/100

This Article is brought to you for free and open access by the Earth and Atmospheric Sciences, Department of at DigitalCommons@University of Nebraska - Lincoln. It has been accepted for inclusion in Papers in the Earth and Atmospheric Sciences by an authorized administrator of DigitalCommons@University of Nebraska - Lincoln. 


\title{
Reconstructing sea-level change from the internal architecture of stromatolite reefs: an example from the Mesoproterozoic Sulky Formation, Dismal Lakes Group, arctic Canada
}

\author{
Linda C. Kah, Julie K. Bartley, Tracy D. Frank, Timothy W. Lyons
}

\begin{abstract}
The Mesoproterozoic Dismal Lakes Group, arctic Canada, contains a relatively thin, yet regionally extensive stromatolitic reef complex that developed subtidally during a major transgression, shoaled to sea level, and was overlain by intertidal to supratidal carbonate and evaporite strata. The September Lake reef complex exhibits a complex internal architecture that records the interaction between stromatolite growth and changes in accommodation space derived from both higher order (4th- or 5th-order, parasequence-scale) changes in sea level and the variable bathymetry of the sea floor. Reef growth, which was initiated during three sea-level cycles, records progressive marine transgression over depositional lows that were formed during pre-reef subaerial exposure and erosion of the underlying strata. A fourth sealevel cycle, represented by spectacular coniform stromatolites with $>10 \mathrm{~m}$ of synoptic relief, marks a more dramatic rise in sea level and establishment of the main reef complex. Aggradation and eventual shoaling of the reef complex occurred over an additional six sea-level cycles. Only basinward regions of the September Lake reef complex preserve vertical stacking of reefal packages in response to sea-level fluctuations. In contrast, in the main reef core, sea-level fluctuations resulted in subaerial exposure of the reef top, variable karst development, and the progressive infilling of reef topography by progradational reef elements. Assessment of stromatolite growth patterns reveals the complex nature of the reef architecture and permits the determination of higher order changes in relative sea level that were responsible for reef development.
\end{abstract}

Résumé : Le Groupe de Dismal Lakes (Mésoprotérozoïque), de l'Arctique canadien, contient un complexe récifal de stromatolithes, relativement mince mais d'une grande étendue, qui s'est développé sous le niveau des hautes marées durant une transgression majeure; il a été remonté au niveau de la mer et ensuite il a été recouvert par des strates de carbonate et d'évaporites intertidales à supratidales. Le complexe récifal de September Lake possède une architecture interne complexe qui enregistre l'interaction entre la croissance des stromatolithes et les changements dans les lieux habités, lesquels découlent de changements du niveau de la mer d'ordres supérieurs (4e ou 5e ordre à l'échelle de la paraséquence) et de la bathymétrie variable du plancher océanique. La récif a commencé à croître durant trois cycles de changement du niveau de la mer qui enregistrent une transgression marine progressive par-dessus des creux de déposition crées durant l'exposition sub-aérienne, avant la formation du récif, et l'érosion des strates sous-jacentes. Un quatrième cycle de fluctuation du niveau de la mer, représenté par des stromatolithes remarquables de forme conique ayant plus de 10 mètres de relief synoptique, marque une élévation du niveau de la mer plus spectaculaire et l'établissement du principal complexe récifal. L'aggradation et l'éventuelle remontée du complexe récifal se sont produites au cours de six autres cycles de changement du niveau de la mer. Uniquement les régions du côté du bassin du complexe récifal de September Lake gardent l'empilement vertical des ensembles récifaux en réponse aux fluctuations du niveau de la mer. À titre de comparaison, dans le noyau du récif principal, les fluctuations du niveau de la mer ont causé l'exposition subaérienne du sommet du récif, le développement variable de karsts et le remplissage progressif de la topographie du récif par des éléments récifaux de progradation. L'évaluation des patrons de croissance des stromatolithes révèle la nature complexe de l'architecture du récif et permet de déterminer les changements d'ordre supérieur des niveaux relatifs de la mer qui sont responsables du développement du récif.

[Traduit par la Rédaction]

Received 30 June 2005. Accepted 2 February 2006. Published on the NRC Research Press Web site at http://cjes.nrc.ca on 29 June 2006.

Paper handled by Associate Editor B. Chatterton.

L.C. Kah. ${ }^{1}$ Department of Earth and Planetary Sciences, University of Tennessee, Knoxville, TN 37996, U.S.A.

J.K. Bartley. Department of Geosciences, University of West Georgia, Carrollton, GA 30118, U.S.A.

T.D. Frank. Department of Geosciences, University of Nebraska, Lincoln, NE 68588, U.S.A.

T.W. Lyons. Department of Earth Sciences, University of California, Riverside, CA 92521, U.S.A.

${ }^{1}$ Corresponding author (e-mail: lckah@utk.edu). 


\section{Introduction}

Despite the biological complexity of reef ecosystems, the changing nature of reef constituents through time (Kiessling 2002), and the complex nature of reef growth (Wood 1999), the relationship between the large-scale geometry of reefs and changes in relative sea level are relatively well understood (James and Bourque 1992). With increasing accommodation space, driven by either tectonic subsidence or sea-level rise, Phanerozoic reefs typically preserve aggradational or backstepping stratal relationships. In contrast, decreasing accommodation space driven by tectonic uplift, depositional filling of available accommodation space, or sea-level fall, commonly results in progradation of the reef over basinal sediments and the eventual infilling and subaerial exposure of the reef top. Proterozoic stromatolitic and calcimicrobial reef architectures exhibit comparable relationships between large-scale changes in reef geometry and changes in relative sea level (Grotzinger 1989; Narbonne and James 1996; Turner et al. 1997; Lemon 2000). In particular, several Mesoproterozoic (Narbonne and James 1996) and Neoproterozoic (Turner et al. 1997; Lemon 2000) reefal deposits reveal vertical stacking of reef packages that record expansion, contraction, progradation, backstepping, and subaerial exposure of the reef system in response to major fluctuations in relative sea level. In these cases, coeval facies changes in off-reef strata support reconstructions of reef growth in response to changing sea level.

The relationship between changes in relative sea level and the internal architecture of Proterozoic reefs is less well understood. The morphological irregularity of stromatolitic and calcimicrobial framework components (Turner et al. 2000), frequent lack of distinctive morphological end members, and a "self-similarity" in the hierarchical scaling of stromatolitic growth forms (Narbonne and James 1996) typically obscures reef architecture. Here, we examine a relatively thin $(<40 \mathrm{~m})$ yet laterally extensive $\left(>2400 \mathrm{~km}^{2}\right)$ reef complex within the Mesoproterozoic Dismal Lakes Group. The purpose of this paper is to (1) document stromatolite growth forms within the September Lake reef complex and the superpositional relationships that define internal reef architecture, (2) interpret stromatolitic growth in terms of response to changes in relative sea level, and (3) construct a sequence-stratigraphic model for reef growth that encompasses changes in accommodation space derived from both higher order changes in relative sea level and the evolution of sea-floor bathymetry during reef growth.

\section{Dismal Lakes Group}

\section{Regional geologic setting and age}

The north-dipping Coppermine homocline, which straddles the border of the Northwest Territories and Nunavut, arctic Canada, is represented by $>4000 \mathrm{~m}$ of unmetamorphosed and virtually undeformed siliciclastic, carbonate, and volcanic rocks that unconformably overlie Paleoproterozoic ( 1.93$1.85 \mathrm{Ga}$; Hoffman and Bowring 1984) metamorphic and volcanic rocks of the Great Bear Batholith and McTavish Supergroup (Hildebrand 1981). The homocline succession is composed of the predominantly sedimentary Hornby Bay and Dismal Lakes groups (Kerans et al. 1981) and regionally extensive, extrusive volcanics of the Coppermine River Group (Barager and Donaldson 1973), which are unconformably overlain by carbonate and siliciclastic strata of the Neoproterozoic Rae Group, Shaler Supergroup (Rainbird et al. 1996).

The $>1500 \mathrm{~m}$ thick Dismal Lakes Group is exposed in a sinuous belt stretching from Great Bear Lake to Coronation Gulf (Fig. 1). Basin development during the Dismal Lakes deposition was governed in part by reactivation of antecedent structural elements. Higher rates of subsidence to the west of a major structural hinge (Leith Line) during much of Dismal Lakes time resulted in significant deepening and thickening of depositional units west of the September Lake High (Kerans et al. 1981). This effect was heightened by the reactivation of a series of northeast-trending structures (e.g., Teshierpi Fault) before and during Dismal Lakes deposition (Cook and MacLean 1992, 1996).

The age of the Dismal Lakes Group is constrained by a combination of geochronological and chemostratigraphic data. The Narakay volcanic complex, the offshore equivalent of the upper Hornby Bay Group (Ross 1982), contains $1662 \pm$ $8 \mathrm{Ma}$ feldspar-phyric dykes and volcanic breccias $\left(\mathrm{U}-\mathrm{Pb}_{\mathrm{zircon}}\right.$; Bowring and Ross 1985), and it constrains the maximum age of the Dismal Lakes Group. However, the identification of subsurface strata west of the exposed outcrop belt (Aitken and Pugh 1984; Cook and Taylor 1991) suggests that the Hornby Bay - Dismal Lakes contact is regionally unconformable. Seismic interpretations indicate a period of compressional tectonism that led to regional block faulting and truncation of the Hornby Bay Group prior to the onset of Dismal Lakes deposition (Forward Orogeny; Cook and MacLean 1995). Cook and MacLean (1995) related the Forward Orogeny to the Racklan Orogeny (Parrish and Bell 1987) and the East Kootenay Orogeny, which is believed to have terminated Belt Supergroup deposition at $\sim 1370 \mathrm{Ma}$ (Anderson and Davis 1995; Doughty and Chamberlain 1996). Regional tectonic constraints thus suggest that deposition of the Dismal Lakes Group commenced sometime after $1370 \mathrm{Ma}$, which is consistent with chemostratigraphic data from the upper Dismal Lakes Group (Dease Lake, Sulky, and Greenhorn formations) that suggests a depositional age of $\sim 1300 \mathrm{Ma}$ (Frank et al. 2003). Cessation of Dismal Lakes deposition is marked by emplacement of the $1270 \pm 4$ Ma Muskox intrusion (U-Pb $b_{\text {baddelyite }}$; LeCheminant and Heaman 1989) and extrusion of the $1267 \pm 2$ Ma Coppermine River Group

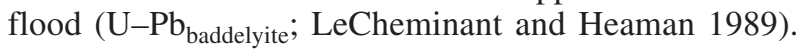

\section{Stratigraphic framework}

The Dismal Lakes Group consists of the siliciclasticdominated LeRoux, Fort Confidence, and Dease Lake formations and the carbonate-dominated Kendall River, Sulky, and Greenhorn formations (Fig. 2; Ross and Kerans 1988). Basal strata consist of fluvial and marginal marine quartz arenite and terrigenous mudstone that record the gradual development of a low-relief, siliciclastic shoreline (Kerans et al. 1981). The deposition of the overlying Kendall River Formation marks the transition from siliciclastic- to carbonatedominated facies, and it records the initiation of the Dismal Lakes carbonate platform, which persisted through the rest of Dismal Lakes Group deposition.

The strata of the overlying Sulky Formation is divided into three informal members that record the drowning of a 
Fig. 1. Geologic map of the Coppermine Homocline showing outcrop extent of the Dismal Lakes Group and major basement features. Reactivation of the Leith Line and Teshierpi Fault during Dismal Lakes deposition resulted in variable east-west subsidence a westward deepening of the basin. The main reef complex crops out only east of the Teshierpi Fault in the region of September Lake, with flanking microbial buildups (Kerans and Donaldson 1989) occupying the western Dismal Lakes region. SL, September Lake; DL, Dismal Lakes. Fm., Formation.

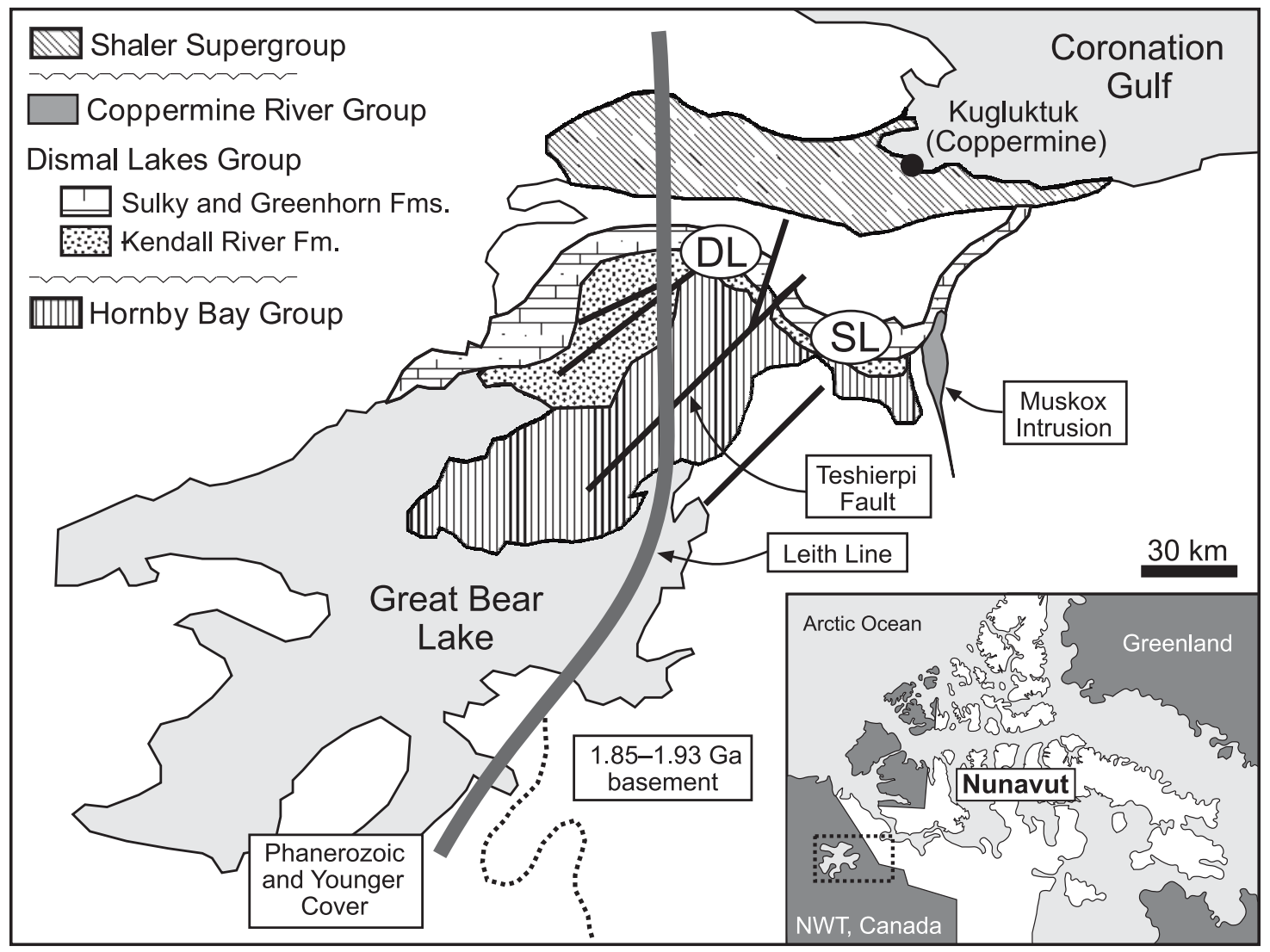

peritidal platform and the development of the September Lake stromatolite reef complex, a return to peritidal deposition, and the eventual subaerial exposure of the eastern platform region (Kerans et al. 1981). The overlying Greenhorn Formation is divided into two informal members (Kerans et al. 1981). The lower Greenhorn member overlies stromatolitic carbonates and a distinctive evaporite and (or) chert-clast collapse breccia of the uppermost Sulky Formation, and it marks a return to peritidal carbonate deposition. The contact between lower and upper Greenhorn members is unconformable and marked by karst features, including sand- and flowstone-filled grikes, cave-floor stream deposits, and collapse breccias up to $30 \mathrm{~m}$ thick (Kerans and Donaldson 1988). Kerans (1983) suggested that karst formation resulted from $>60 \mathrm{~m}$ of tectonic uplift east of the Teshierpi Fault, which is associated with emplacement of the Muskox intrusion. The extent of palaeokarst development (from the September Lake High to the Parry Bay - Kanuyak formations $>300 \mathrm{~km}$ to the east; Pelechaty et al. 1991) and the abundance of terrigenous material overlying the disconformity, however, suggests that uplift was of greater regional extent, perhaps coincident with a fall in sea level (Kerans and Donaldson 1988). Peritidal strata of the upper Greenhorn record the re-establishment of the carbonate platform following subaerial exposure and karst development. Finally, soft sediment deformation structures in the uppermost Greenhorn Formation record interaction between wet sediment and hot lava; they indicate that Dismal Lakes Group deposition ended abruptly with extrusion of the overlying Coppermine River Group (Kerans et al. 1981).

\section{September Lake reef complex}

\section{Lithology and sequence stratigraphic framework}

The Sulky Formation is divided into three informal members that represent pre-reef deposition, the development of an extensive reef and off-reef succession, and post-reef deposition (Fig. 2; Kerans et al. 1981; Kerans and Donaldson 1989). The lower Sulky member consists of flaggy bedded, structureless to parallel-laminated detrital dolostone with thin interbeds of red, black, and green shale; it marks an abrupt transgression over peritidal stromatolitic, oolitic, and intraclastic grainstones and interbedded mudcracked shale of the Kendall River Formation. Increased rates of subsidence to the west of the Leith Line and Tesheirpi Fault are marked by the presence of rhythmic and graded bedding of dolostone units, occurrences of stratiform breccias and soft-sediment deformation features, and a predominance of black and green shale (Kerans et al. 1981).

The transition from lower to middle members of the Sulky Formation is marked across the basin by the development of a regional sequence boundary and the abrupt appearance of microbialite-dominated facies. In the east, this sequence 
Fig. 2. Generalized stratigraphy of the Dismal Lakes Group, modified from Kerans et al. (1981), and four composite sections through a $15 \mathrm{~km}$ wide, down-dip transect of the September Lake reef complex. The reef complex comprises the middle $(m)$ member of the Sulky Formation, overlies a prominent type 1 sequence boundary (SB1), and represents deposition during transgressive (TST) and early highstand (HST) systems tracts. The overlying upper Sulky Formation represents peritidal carbonate deposition during late highstand and lowstand (LST) deposition of a regional evaporite unit. Subaerial exposure and dissolution of evaporites marks the major type 2 sequence boundary (SB2). Variable thickness of the reef complex reflects the erosional topographic relief of underlying strata and greater subsidence of basinward regions during reef development. The present-day land surface results in poor preservation of the stratigraphically highest sections of the reef near September Lake. Heavy dashed line (marked with an asterisk) marks the base of the parasequence PS-4. Ft Conf, Fort Confidence; GH, Greenhorn; $l$, lower; $m$, middle; $u$, upper.

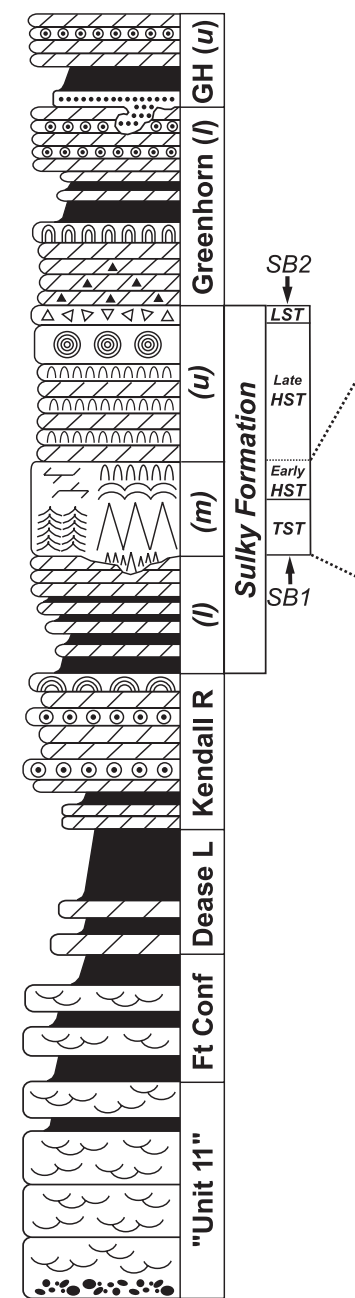

boundary is represented by an erosional unconformity that locally preserves up to $3 \mathrm{~m}$ of erosional relief (Fig. 3). Variable thickness and lateral discontinuity of lowermost stromatolite buildups of the September Lake reef complex suggest that as much as $20 \mathrm{~m}$ of erosional relief may occur at this boundary. In contrast, the lateral continuity of lowermost middle Sulky strata west of the Teshierpi Fault suggests conformable deposition offshore of the reef complex.

The September Lake reef complex is represented by a $20-$ $50 \mathrm{~m}$ thick, laterally persistent succession of domal, conical, and branching conical stromatolites that crops out extensively in the region surrounding September Lake (Fig 1; Donaldson 1976; Kerans and Donaldson 1989). The September Lake reef complex may be correlative with stromatolitic reef development in the Parry Bay Formation, Elu and Bathurst Inlet regions, $>300 \mathrm{~km}$ to the east (Naoyak reef; Campbell 1978, 1979; Kerans et al. 1981). Throughout its extent, the
September Lake reef complex is marked by the presence of conical stromatolites with high synoptic relief constructed through in situ carbonate precipitation (Fig. 4A), an absence of erosional scour and reworking of stromatolite debris, and an absence of detrital terrigenous or carbonate sediment in inter-stromatolite regions. Together, these characteristics suggest a cratonward backstepping of the basin shoreline and the development of a deep-water reef tract.

West of the Tesheirpi Fault (Fig. 1; Dismal to Bebensee Lake region), the reef complex is replaced by a series of discontinuous, 2-20 m thick bioherms of unusual cuspate microbialites interbedded with microbialite breccia (cf. flank facies of Kerans and Donaldson 1989). Cuspate microbialite buildups are characterized by an absence of interstitial detrital terrigenous or carbonate sediment and the presence of thick coatings of herringbone cement. Herringbone cement is an unusual cement morphology consisting of elongate crystals 
Fig. 3. Erosional unconformity (dotted line) separating mediumbedded, flaggy dolostone of the lower Sulky Formation from irregular domal stromatolitic dolostones of the basal reef complex. Person in the foreground is for scale. Erosion of underlying strata of the lower Sulky Formation resulted in up to $20 \mathrm{~m}$ of depositional relief.

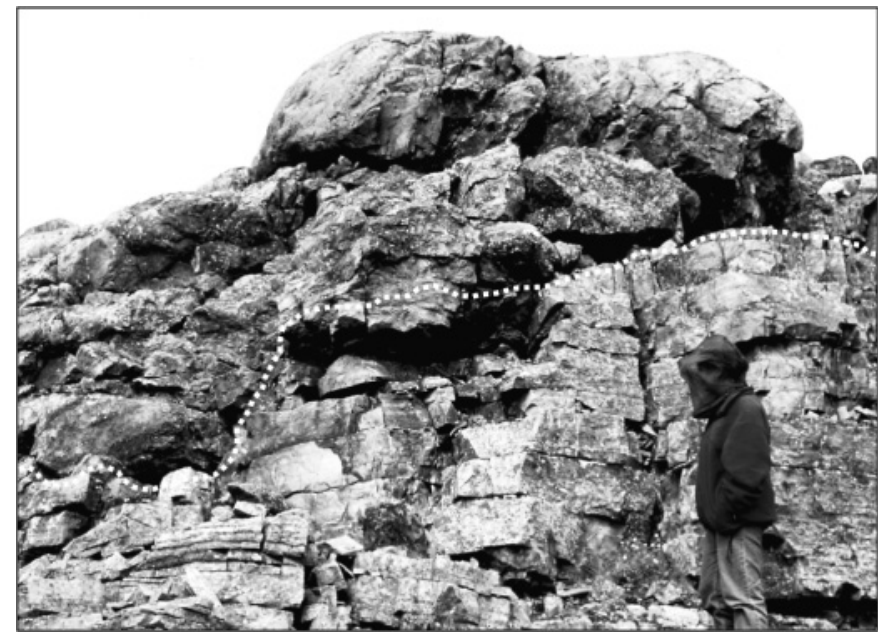

in which the $c$-axis rotates through growth, from orientations parallel to perpendicular to crystal elongation (Sumner and Grotzinger 1996a). This unusual mode of crystal growth is most prevalent as a sea-floor precipitate in the Archean and as a void-filling cavity cement in younger successions (de Wet et al. 1999). It has been attributed to both the presence of dissolved ferrous iron under conditions of regional anoxia (Sumner and Grotzinger 1996b) and to the presence of locally elevated levels of $\mathrm{CO}_{2}$ derived from organic decomposition (Tourre and Sumner 2000). The presence of extensive herringbone precipitation in basinal facies of the middle Sulky Formation, as well as isolated occurrences in the main reef core, support the presence of a deep-water and regionally dysoxic to anoxic water body during development of the September Lake reef complex (Kah et al. 1999).

Shoaling of the September Lake reef complex occurs over a 10-25 m thick interval and marks the transition to the upper member of the Sulky Formation. Thick-bedded dolomicrites, columnar and conical stromatolites, and oolitic and intraclastic grainstones (Fig. 4B) that compose the upper Sulky Formation basinward of the main reef complex are replaced, east of the Tesheirpi Fault, by fenestral and pisolitic dolostone (Fig. 4C) interbedded with dolomicrite and quartzose dolostone. This return to high-energy, shallow-water facies across the Dismal Lakes region indicates re-establishment of a low-relief, waveswept peritidal platform. Throughout the Dismal Lakes outcrop belt, the top of the upper Sulky member is marked by a distinctive, 1-5 m thick stromatolitic horizon that is interbedded with cauliflower chert, chert breccia, relict anhydrite (Fig. 4D), and minor terra rosa, suggesting evaporitic conditions and development of regional post-reef sequence boundary.

Lithologic and stratigraphic features indicate that the September Lake reef complex developed during a single 3rd-order stratigraphic sequence (Emery and Myers 1996; Miall 1997), wherein a type 1 sequence boundary (SB1, Fig. 2) marks the base of the reef complex; deep-water deposition of the main reef complex and flanking buildups indicate the development of transgressive (TST, Fig. 2) and early highstand systems tracts (Early HST, Fig. 2); and reef shoaling and development of a superjacent peritidal carbonate platform signal the development of a late highstand systems tract (Late HST, Fig. 2). Regional evaporitic facies that cap the Sulky Formation mark lowstand deposition (LST, Fig. 2) and the development of a post-reef, type 2 sequence boundary (SB2, Fig. 2).

\section{Stromatolites of the September Lake reef complex}

\section{Metre-scale conical stromatolites}

Metre-scale conical stromatolites consist of a central axial zone and steeply dipping $\left(60^{\circ}-85^{\circ}\right)$, wall-parallel laminae that preserve a synoptic relief of $1-3 \mathrm{~m}$ and form stratigraphic packages $<4.5 \mathrm{~m}$ in thickness (Fig. 5A). Metre-scale cones are typically $20-40 \mathrm{~cm}$ in diameter and circular to slightly ovate in cross-section. Where present, interstromatolitic sediment is micritic, but the proximity of adjacent cones typically limits the space available for sediment deposition. More commonly, the proximity of adjacent cones results in the lateral linkage of conical laminae, and micrite deposition leads to a preferential thickening of laminae at the interface between adjacent cones. Continued thickening of laminae between cones ultimately results in a gradual upward decrease in synoptic relief of the cones. More rarely, closely spaced adjacent cones coalesce to form a single, larger conical structure.

\section{Decametre-scale conical stromatolites}

Decametre-scale conical stromatolites, as with their smaller counterparts, consist of a distinct axial zone and steeply dipping $\left(45^{\circ}-85^{\circ}\right)$ wall-parallel laminae. In the September Lake reef complex, these giant cones form a single, laterally traceable stratigraphic unit $\sim 15 \mathrm{~m}$ thick. Three distinct morphologies correlate with both the distance between adjacent axial zones and the geographic position within the reef complex. Decametre-scale cones with spacing of axial zones $>15 \mathrm{~m}$ occur most commonly north and east of September Lake (Fig. 5B). These widely spaced cones typically preserve a single axial zone and laminae that dip between $45^{\circ}$ and $52^{\circ}$; more rarely, these large cones contain two to four closely spaced $(<50 \mathrm{~cm})$ laterally linked axial zones that are enveloped by common outer laminae. Although sub-recent glacial erosion has left only 6-8 $\mathrm{m}$ of this package exposed in the region north of September Lake, geometrical relationships suggest a synoptic relief of 10-13 m for these cones. Interstromatolitic regions are composed of secondary stromatolite growth (see later in the text).

Decametre-scale cones with 2-5 m spacing of axial zones are exposed near the northwest corner of September Lake (Fig. 5C). These closely spaced, yet evenly distributed, cones typically preserve a single axial zone and laminae that dip between $67^{\circ}$ and $83^{\circ}$. Despite the close spacing of axial zones, these cones show little to no lateral linkage between adjacent stromatolites through most of cone growth, resulting in a high synoptic relief (to $12 \mathrm{~m}$ ). Only in the final stages of cone growth, when adjacent cones abut one another, does lateral linkage of laminae occur. Lateral linkage of stromatolites is associated with a reduction in the synoptic relief of the reef surface to $<5 \mathrm{~m}$. 
Fig. 4. Petrographic fabrics from the Sulky Formation. (A) Fine-scale dolomitic replacement of acicular aragonite comprising laminae of coniform stromatolites of the September Lakes reef complex. Scale bar $=0.5 \mathrm{~mm}$. (B) Oolitic and peloidal grainstone showing finescale, dolomitic replacement of radial ooids. Scale bar $=0.5 \mathrm{~mm}$. (C) Pisolitic grainstone showing fine-scale, dolomitic replacement of pisolitic cortices, microsparitic meniscus cements, and sparry intergranular cements, marking a return to peritidal carbonate deposition in the post-reef succession. Scale bar $=1.0 \mathrm{~mm}$. (D) Relict anyhydrite within a quartz-replaced intraclast from a prominent evaporite breccia that marks the top of the upper Sulky Formation. Scale bar $=0.1 \mathrm{~mm}$. All photomicrographs are under crossed-polarized light.
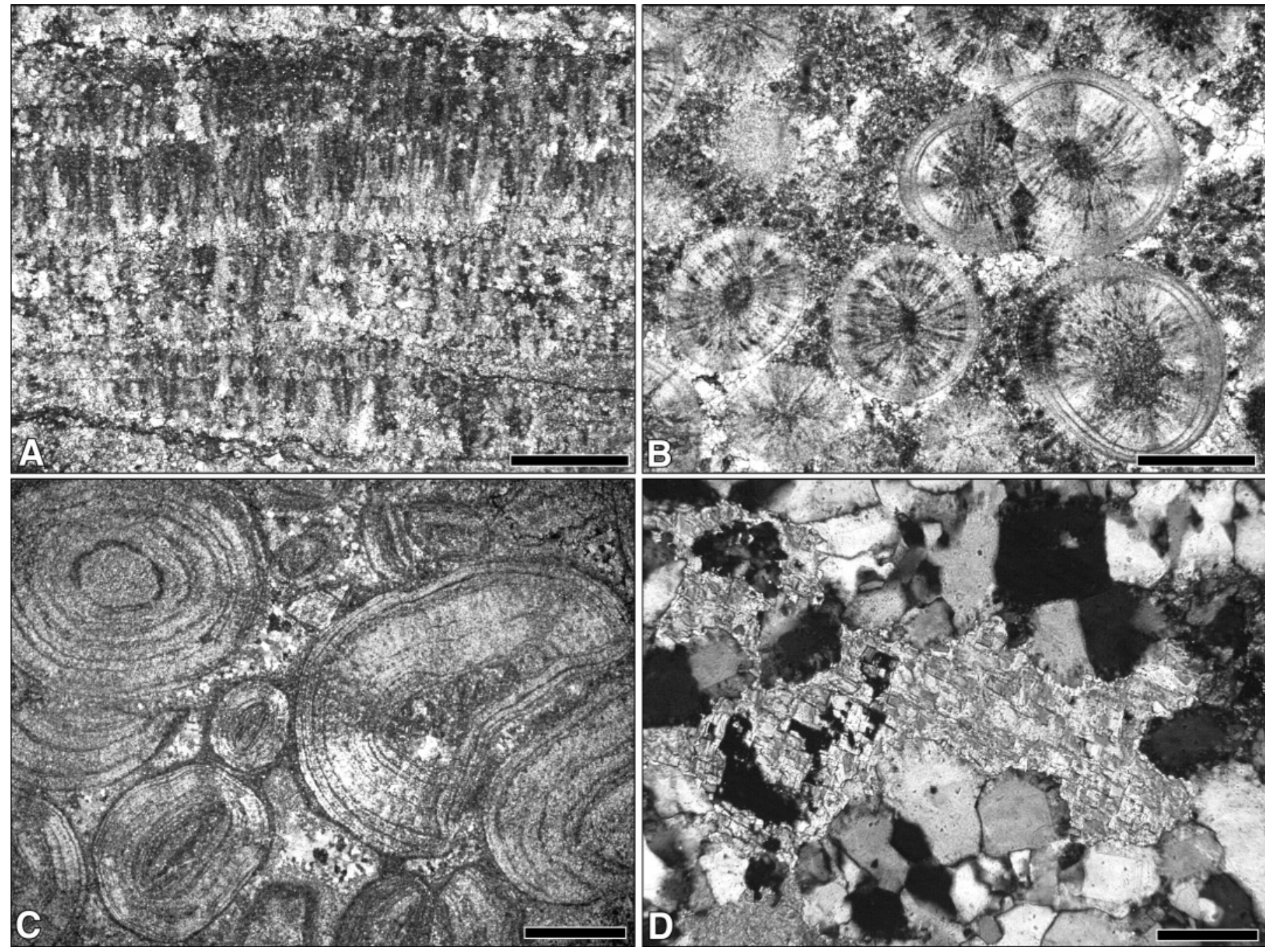

Decametre-scale cones with $<2 \mathrm{~m}$ spacing of axial zones are exposed northwest of September Lake (Fig. 5D). Closepacked spacing of axial zones is associated with asymmetric conical growth and a high degree of lateral linkage between adjacent stromatolites. Lateral linkage of cones results in a lower synoptic relief (typically $<2 \mathrm{~m}$ ), and thickening of laminae at the interface between adjacent cones results in a gradual upward decrease in depositional relief.

\section{Modified and composite conical stromatolites}

Conical stromatolites of the September Lake reef complex are frequently modified by either a change in laminae morphology during continued growth of the stromatolites or by the superposition of secondarily nucleated stromatolites. Most commonly, steep-sided cones accrete both upward and outward and increase their synoptic relief throughout the duration of their growth. In the September Lake reef complex, some horizons containing metre-scale conical stromatolites preserve distances between adjacent axial zones that are greater

than the maximum diameter of the cone. In these cases, interstromatolitic regions are typically filled with micrite or by low-relief unwalled columns that extend outward from the central cone (i.e., referable to the form-genera Jacutophyton). Other metre-scale conical horizons, as well as decametrescale cones, accrete both upward and outward, increasing their synoptic relief, until the outermost laminae impinge upon adjacent cones (Fig. 6A). At this point, stromatolites typically become laterally linked, wherein a single laminae becomes traceable between adjacent cones. Once adjacent cones are linked, they either (1) undergo preferential thickening of laminae at the interface between adjacent cones, or groups of cones, and an upward decrease in synoptic relief; (2) unite into larger conical structures, which continue to grow upward and outward, increasing in synoptic relief; or (3) continue to accrete upward preserving their pre-linkage synoptic relief (cf. Donaldson 1976).

In the first case, laterally linked cones undergo preferential thickening of laminae at the interface between adjacent cones 
Fig. 5. Conical stromatolites of the September Lake reef complex. (A) Closely packed, metre-scale cones marking transgression and early development of the main reef core. Jacob staff is $1.5 \mathrm{~m}$ long. (B) Decametre-scale, widely spaced cones of the main reef core with well-developed axial zones and up to $12 \mathrm{~m}$ of synoptic relief. Person in foreground is for scale. (C) Decametre-scale, closely spaced cones in basinward regions of the reef complex with steeply dipping $\left(75^{\circ}-86^{\circ}\right)$ laminae and a synoptic relief of up to $15 \mathrm{~m}$. People in the foreground are for scale. (D) Closest-packed cones in basinward regions of the reef complex. Intersection of laminae from adjacent cones results in a synoptic relief of only 1-3 m. Person in the foreground is for scale.
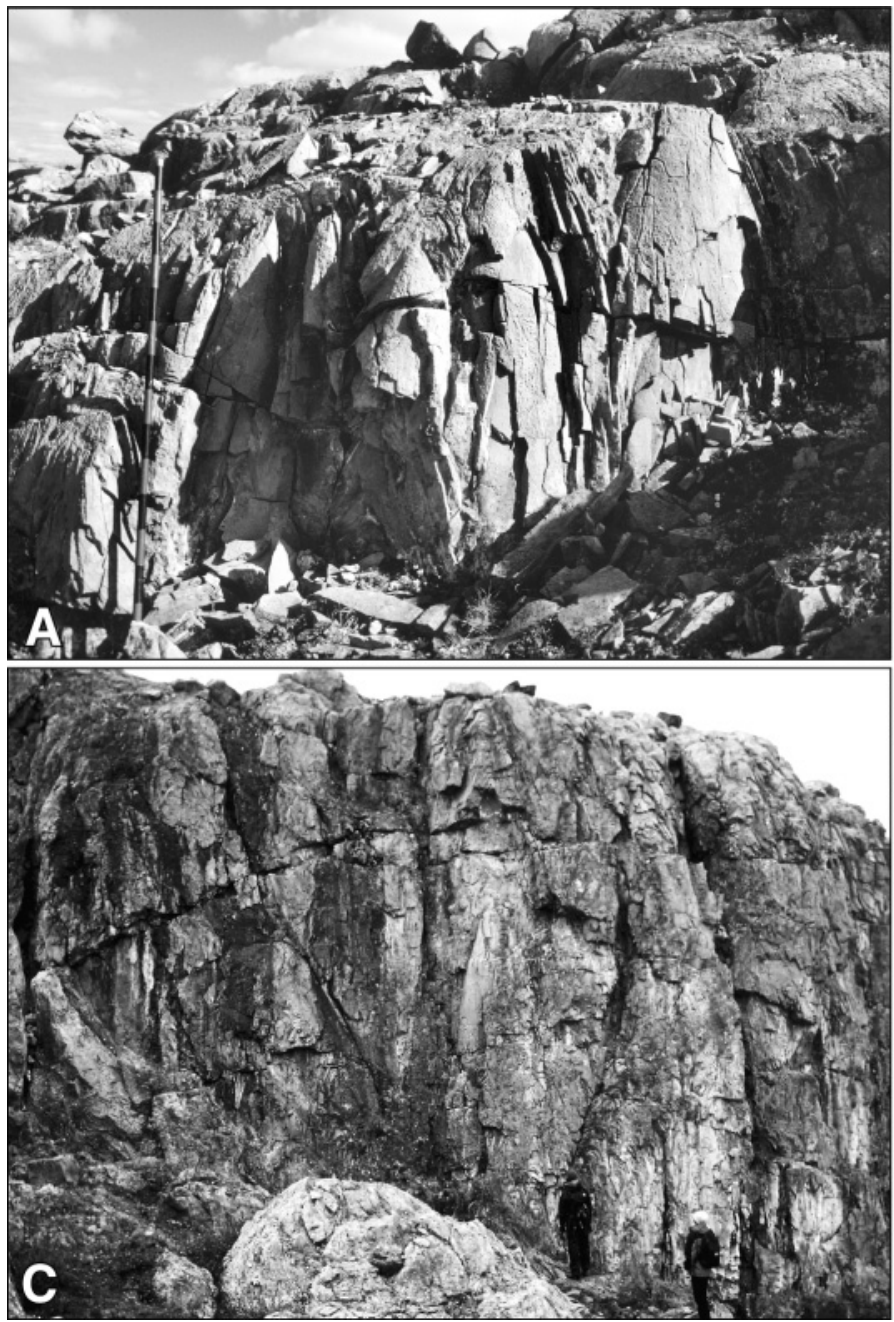

and a gradual upward and outward decrease in synoptic relief (Fig. 6B), resulting in a gradual transition from conical to broad domal stromatolite morphologies. Transitions from conical to domal stromatolite morphologies also occur via the coalescence of closely spaced cones into composite stromatolites and the subsequent shallowing of limb dips.

In contrast, where high synoptic relief is preserved throughout the growth of decametre-scale widely spaced cones, interstromatolitic regions typically preserve several distinct generations of stromatolite growth that postdate cone growth. Secondary stromatolite growth includes successive nucleation of both metre-scale conical and domal stromatolite forms. Closely spaced, metre-scale cones (Fig. 6C) are typically nucleated along the perimetre of underlying giant cones, resulting in asymmetric growth upward and away from the central core (Fig. 6D). Detailed examination of the intersection of cone laminae reveals up to six distinct generations of cone nucleation that occur successively outward from the central core, filling the spaces between adjacent giant cones. A very different growth pattern is observed where domal stromatolites occur
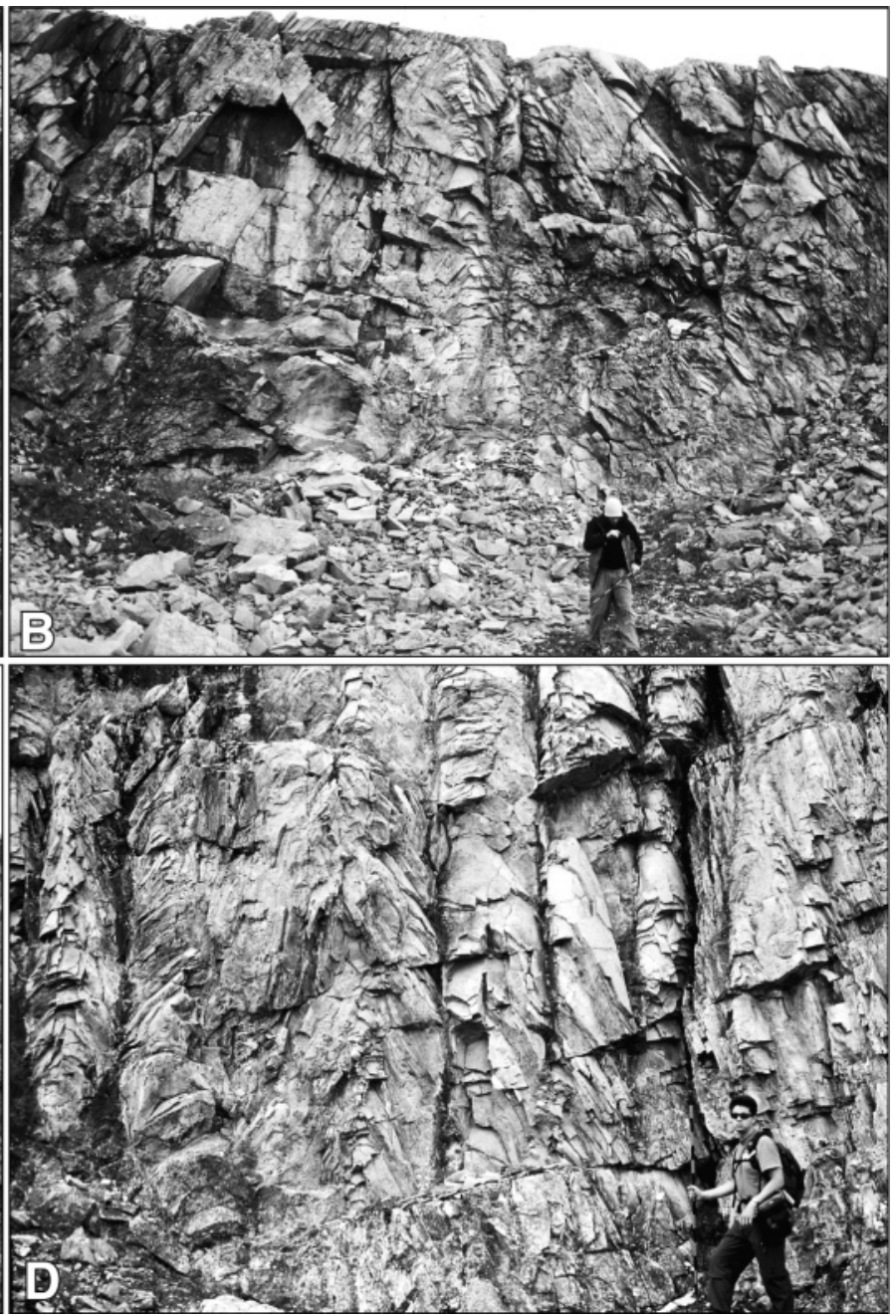

between widely spaced high-relief cones. As with secondary cone growth, nucleation of domal stromatolites also occurred on the margin of giant cones. However, in these cases, rather than preserving evidence of both upward and outward growth, laminae of domal stromatolites become thinner at their tops, marking restriction of upward growth, and show a strong progradation of successive laminae outward from the central cone (Figs. 6E, 6F). Up to six discrete generations of domal stromatolite growth are marked by the successive stacking of these progradational elements (cf. Figs. 8C, 8D).

\section{Columnar and domal stromatolites}

A variety of non-conical stromatolites also occur within the September Lake reef complex, including columnar, branching columnar, and domal forms. Columnar stromatolites occur in stratigraphic packages $2-5 \mathrm{~m}$ thick. Individual columns are typically $10-50 \mathrm{~cm}$ in diameter, preserve a synoptic relief of $<10 \mathrm{~cm}$, and are closely spaced, with $<1 \mathrm{~cm}$ between adjacent columns. In all cases, interstromatolitic regions are filled with microsparitic carbonate. Non-branching columnar 

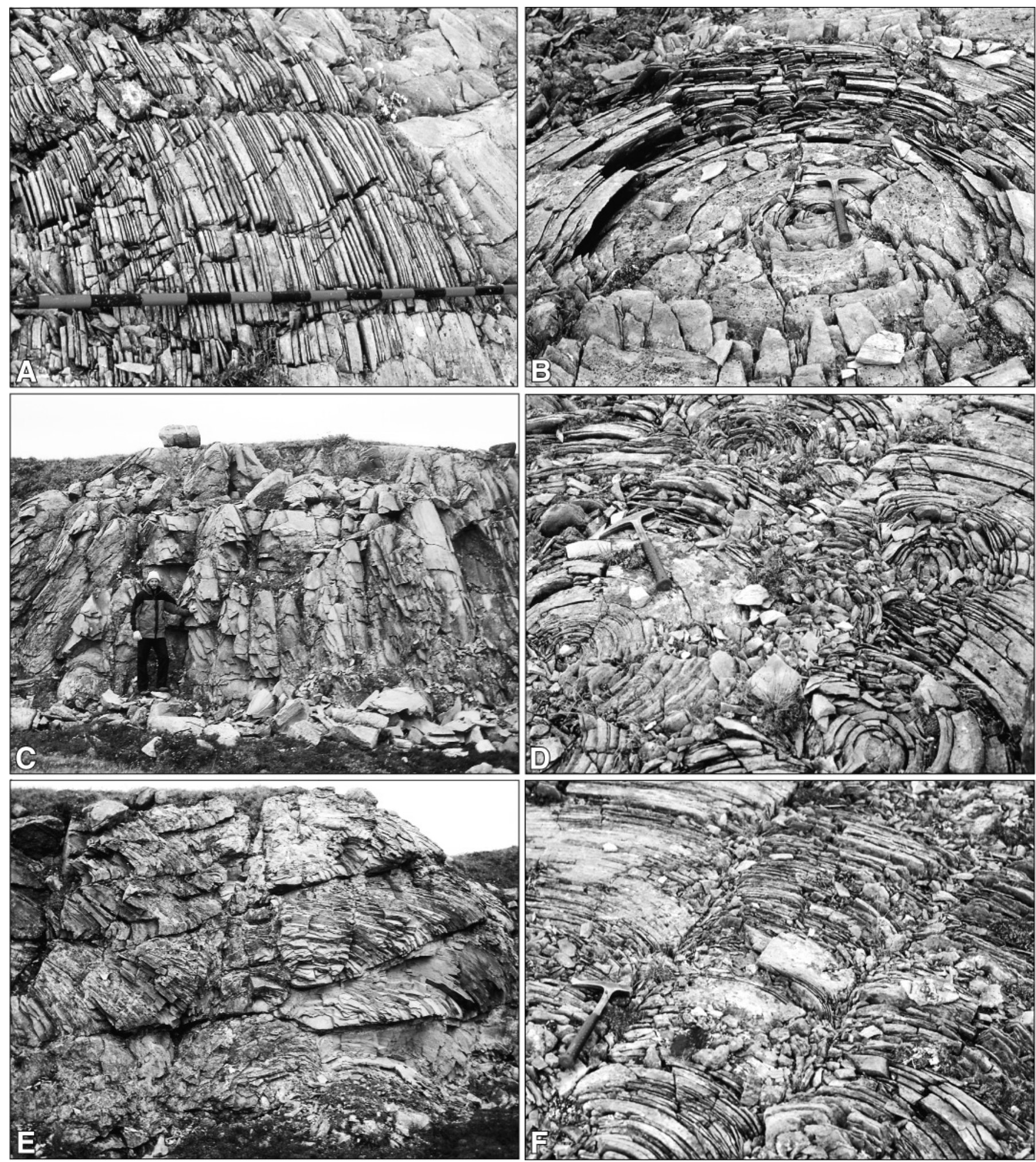

stromatolites form laterally continuous biostromes that occasionally show a west-northwest elongation of the columns in plan view, similar to the inferred depositional dip of the Dismal Lakes platform (Kerans et al. 1981). In contrast, irregularly branching columnar stromatolites form irregular domal bioherms with up to $2 \mathrm{~m}$ of synoptic relief. In plan view, columns within the bioherms frequently show variable elongation with variably elongate columns along the edge of the bioherm and columns with increasingly circular cross-sections near the center of the bioherms. Interstromatolitic space within the bioherms is composed of microsparitic carbonate, and there is no evidence of sediment deposition between bio- 
Fig. 6. Stromatolites of the main reef core. (A, B) Plan views of decametre-scale, widely spaced conical stromatolites: (A) Continuous upward and outward accretion of steeply dipping laminae represents stromatolite growth during the primary transgressive phase of reef development. Jacob staff, for scale, has $10 \mathrm{~cm}$ divisions. (B) With continued accretion, laminae occassionally thicken between adjacent, laterally linked stromatolites, resulting in a gradual shallowing of laminae dips. Hammer is for scale. (C) 1-3 m tall, closely spaced conical stromatolites adjacent a decametre-scale cone. Person in the foreground is for scale. (D) Plan view of secondary cones reveals asymmetric growth patterns that indicate nucleation of cones along the outer edge of preexisting decametre-scale stromatolites. Hammer is for scale. (E) Alternatively, stacked packages of laterally prograding domal stromatolites occur adjacent to giant cones. Laminae of these stromatolites abruptly abut underlying strata, coalesce at their upper margin, and prograde away from decametre-scale cones, suggesting that upward growth was limited by available accommodation space. (F) Progradation of laminae away from the central cone is readily apparent in plan view. Hammer is for scale.

Fig. 7. (A, B) Upturned blocks of the September Lake reef complex showing dissolution and collapse textures inside conical stromatolites. Dissolution is restricted to the internal cone, suggesting that cone tops may have been subaerially exposed at the same time as continued growth of submerged portions. Jacob staff, for scale, has $10 \mathrm{~cm}$ divisions.
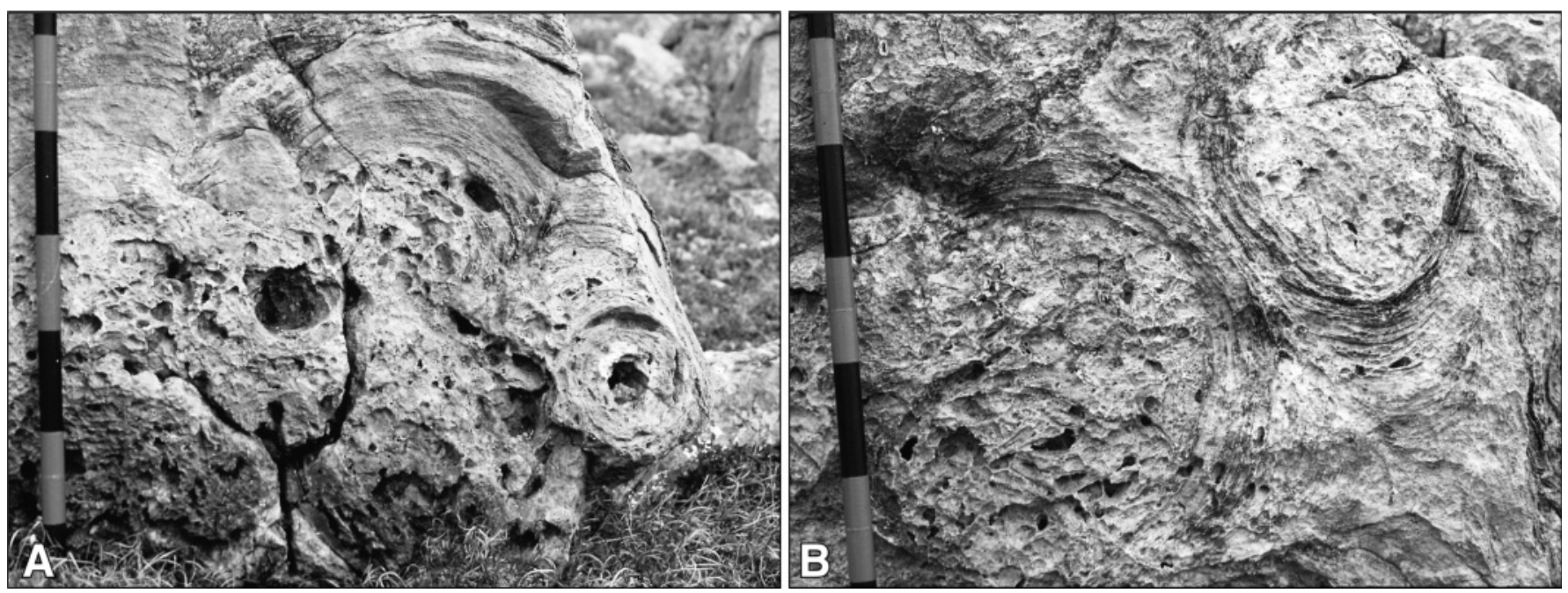

herms. Rather, inter-biohermal regions are filled by successive bioherm generations that prograde laterally away from older bioherms.

Domal stromatolites are relatively rare in the September Lake reef complex. Irregularly shaped high-relief domes (50$200 \mathrm{~cm}$ diameter, with $10-50 \mathrm{~cm}$ of synoptic relief) occur above the basal unconformity (Fig. 3) and commonly show an upward transition to higher synoptic relief, conical morphologies. In contrast, broad low-relief domes $(2-10 \mathrm{~m}$ in diameter, with 10-200 cm synoptic relief) typically overlie conical stromatolites (cf. Figs. 8A, 8B) and show an upward decrease in synoptic relief. Domal stromatolites are more common in the upper member of the Sulky Formation, overlying the main reef complex, where domes $(50-200 \mathrm{~cm}$ in diameter, with $<20 \mathrm{~cm}$ synoptic relief) occur interbedded with fenestral and pisolitic carbonate facies. All domal stromatolite facies are variously interbedded with thin to thick (1-15 cm thick) beds of laminated microsparitic carbonate.

\section{Reef architecture}

The distribution of different stromatolite morphologies defines a complex internal architecture of the September Lake reef complex. The boundary that separates the lower and middle members of the Sulky Formation is unconformable across the September Lake High, but inaccessible cliffside exposures prohibit detailed mapping of the surface. One to four distinct stromatolite packages occur above the contact with the lower Sulky Formation: irregular domal-to-conical stromatolites, metre-scale cones, metre-scale branching cones (i.e., Jacutophyton), and decametre-scale cones (cf. Fig 9). Irregular domal-to-conical stromatolites, where present, always occur directly atop the pre-reef Sulky unconformity (Fig. 3) and are, in turn, overlain by one or two distinct packages of metre-scale (Fig. 5A) or branching cones. Successive packages of metre-scale cones typically become larger in diameter and show an increase in synoptic relief. Metre-scale stromatolite packages occur most frequently north and east of September Lake and typically cannot be traced laterally for more than several kilometres, and frequently for $<100 \mathrm{~m}$, suggesting that their distribution is limited by topographic relief on the underlying unconformity. In contrast, decametre-scale conical stromatolites are traceable across the September Lake High, where they overlie laterally discontinuous metre-scale cones or branching cones or directly overlie the contact with the lower Sulky Formation.

The morphology of decametre-scale cones, however, varies significantly from east to west across the reef complex, resulting in variable reef topography during this growth stage. Widely spaced cones (Fig. 5B) occur predominantly north and east of September Lake and result in 10-13 m of local variation in reef topography between adjacent cones. Widely spaced cones are replaced to the west by more closely spaced 
Fig. 8. Parasequence stacking patterns of the September Lake reef complex. (A, B) Basinward regions of the reef showing sequential stacking of stromatolitic packages. Parasequences PS4, PS5, PS6 are separated by parasequence boundaries (dotted lines). Conical stromatolites represent upward growth during transgressive systems tracts (TST) events. In PS4, conical stromatolites are capped by large, low-relief domal stromatolites that developed during a late highstand to lowstand (LST) deposition. In PS5 and PS6, conical stromatolites show evidence of subaerial exposure and karst development at parasequence boundaries. Outcrop is $20 \mathrm{~m}$ high. (C, D) Main reef core. Widely spaced, decametre-scale cones of PS4 are surrounded by sequential stacking of progressively thinner, progradational stromatolitic packages (PS5-PS10) separated by parasequence boundaries (dotted lines). Prograding stromatolitic elements record infilling and shoaling of the reef complex. Outcrop is $3.5 \mathrm{~m} \mathrm{high}$.
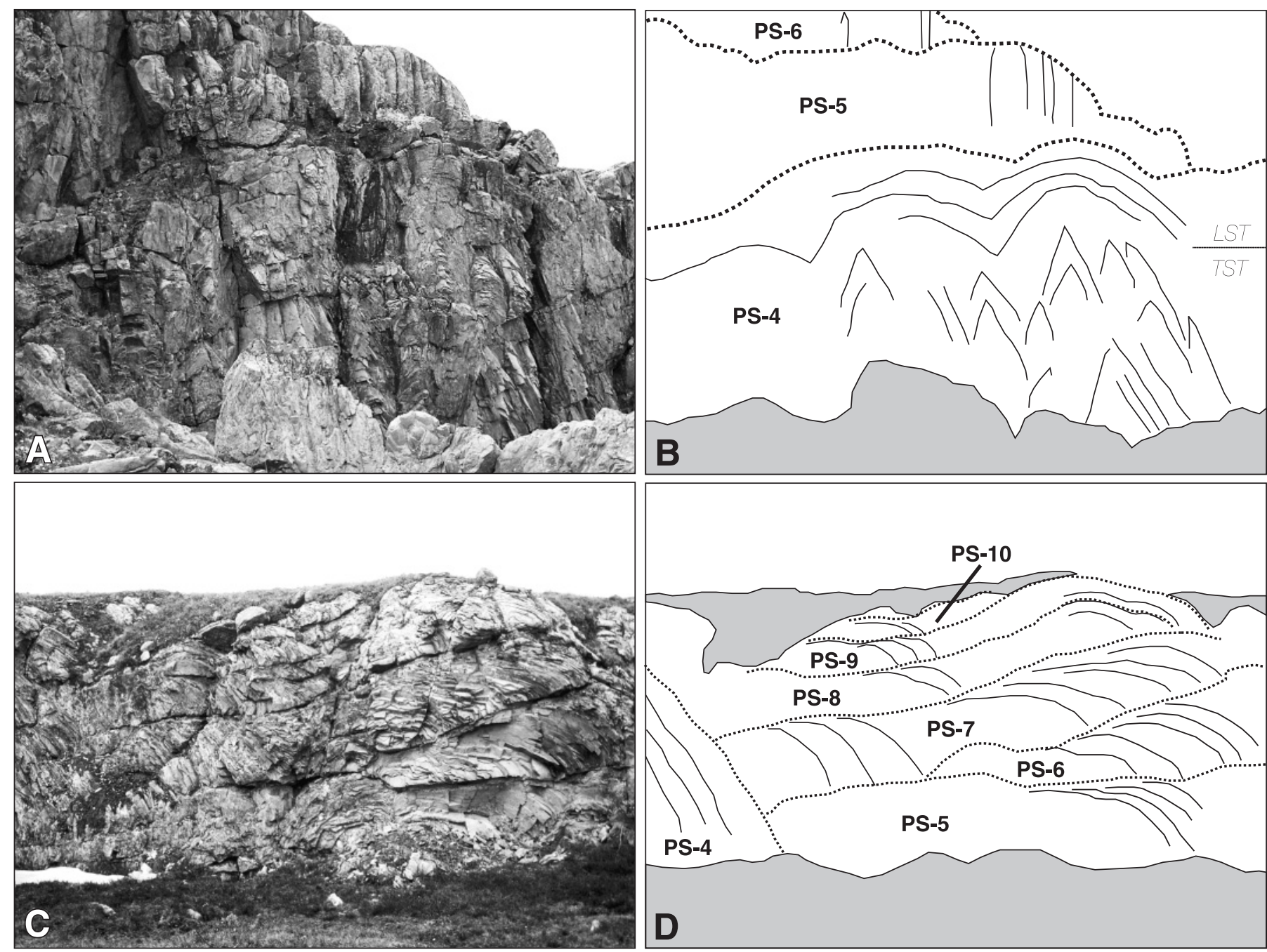

cones (Figs. 6C, 6D), which show an increasing amount of lateral linkage and a successive decrease in synoptic relief of the growth surface.

Stromatolite packages that overlie decametre-scale cones also show regional variation. North and east of September Lake, up to six generations of stromatolite growth are represented by secondarily nucleated metre-scale cones (Figs. 6C, 6D) or stacked packages of prograding domal stromatolites (Figs. 6E, $6 \mathrm{~F})$ that infill topography between adjacent decametre-scale cones. To the west, close spacing of decametre-scale cones results in little topographic relief of the reef surface; instead decametre-scale cones are stratigraphically overlain by up to six discrete packages of metre-scale cones and columnar stromatolitic bioherms (cf. Fig. 2). Most of these stromatolite packages show evidence of subaerial exposure, including dissolution and development of karst breccias within conical

stromatolites (Figs. 7A, 7B), and erosion and development of terra rosa across columnar bioherm tops. Finally, the reef complex is blanketed by a laterally persistent biostrome of elongate columnar stromatolites that mark the transition to peritidal cycles of the upper Sulky member.

\section{Interpretation of reef development}

Large-scale changes in accommodation space are potentially driven by a combination of eustatic sea-level change, tectonic uplift and (or) subsidence, and sediment infilling. These changes in accommodation space are typically recorded in Proterozoic stromatolite reefs over a number of stratigraphic sequences (10-100 m thick) by vertical changes in the lateral extent of reef growth; distribution of reef talus; progradational, aggradational, or backstepping relationships between reef facies and surrounding strata; and termination of reef 
growth by subaerial exposure or drowning. In contrast, examination of regional stratigraphy indicates that the September Lake reef complex developed during a single composite stratigraphic sequence. Higher order (i.e., 4th- or 5th-order, parasequence-scale) changes in accommodation space are potentially recorded in reefal deposits as well, and may be reflected in the morphology of specific reef elements and the superpositional relationships among these elements.

\section{Stromatolite record of accommodation space}

Although the potential effect of various benthic microbial communities on development of specific facies has yet to be established, it is now generally accepted that stromatolite microfabric is controlled largely by a combination of physiochemical and biological interactions. Stromatolite morphology, on the other hand, is affected primarily by environmental factors, particularly water depth, wave energy, sediment influx, and lithification (cf. Grotzinger and Knoll 1999).

For the purpose of inferring paleo-water depth and reconstructing sea-level change, laminae structure is arguably the single most critical aspect of stromatolite morphology. Each lamina represents the active growth surface of the mat at the time of deposition and therefore records, for that particular instance, the morphology of the depositional surface (i.e., synoptic relief, Donaldson 1976), the relationship between mat growth and sediment deposition (i.e., wall structure, Semikhatov et al. 1979), and the influence of wave and (or) current action on mat growth (i.e., stromatolite elongation, Hoffman 1967). The relationship between stromatolite morphology and depositional setting has been investigated by a number of researchers and summarized by Hoffman (1976) and Grotzinger (1989), wherein specific stromatolite morphologies appear to characterize distinct depositional settings and synoptic relief is well correlated with inferred paleowater depth. Upper intertidal to supratidal environments are characterized by stromatolites with low synoptic relief, frequently associated with intraclastic debris. Intertidal to shallow subtidal (above fair-weather wave-base) environments are characterized by relatively low-relief domal and irregular columnar stromatolites that are associated with intraclastic and (or) fine-grained detrital material. Deeper subtidal (below fair-weather wave-base) environments are characterized by high-relief columnar to conical stromatolite forms that lack evidence of interstromatolitic sediment deposition.

Because successive laminae represent the accretion of the stromatolite through time, superposition of laminae and relationships between laminae and associated detrital material can be used to infer changes in paleo-water depth. As an example of the potential of stromatolites in interpreting parasequence-scale changes in relative sea level, we provide here a sequence-stratigraphic interpretation of the branching conical stromatolite form Jacutophyton. Jacutophyton (cf. Bertrand-Sarfati and Moussine-Pouchkine 1985) represents the superposition of low-relief, unwalled, columnar to elongate columnar, outward-expanding branches over a central, steep-sided, high-relief cone (i.e., the form-genera Conophyton). The synoptic relief and large height-to-width ratio of the central cone indicates deposition in a low-energy environment with little or no sedimentary influx (Donaldson 1976; Bertrand-Sarfati and Moussine-Pouchkine 1985), such as during marine transgression when the rate of sea-level rise is greatest and backstepping of the shoreline inhibits sediment influx to the basin, and early highstand when accommodation space is at its maximum. In this scenario, accretion of conical laminae would represent upward growth during transgressive and highstand tracts. A lack of evidence for the erosion of conical laminae and the absence of interstromatolitic debris during this growth phase suggests that Conophyton, in general, are a deeper subtidal facies (cf. Donaldson 1976; Hoffman 1976; Bertrand-Sarfati and Moussine-Pouchkine 1985; Grotzinger 1986; Beukes 1987) and that synoptic relief of the central cone was limited by the position of the wave-base. Detailed investigation of the interface between conical and branching elements in Jacutophyton (Kah and Bartley 2004) reveals that branching elements typically initiate from the outermost laminae of the underlying cone and that these laminae frequently show disruption that corresponds to the location of branch development. These observations suggest initiation of branching during a fall in relative sea level, wherein wave-base impinges on the central cone and exposes it to wave action. Disruption of the cone's outermost lamina would then provide substrate for development of branching elements. The low-relief, unwalled, variably elongate structure of branching elements, which develop in concert with the deposition of abundant rip-up clasts in intercolumnnar and interconical regions, indicates branch development in a shallow-water, high-energy depositional environment (i.e., within fair-weather wave-base) during sea-level lowstand. In this interpretation, a single horizon of Jacutophyton would be interpreted as a single, complete parasequence.

\section{Dynamics of reef growth}

The stromatolitic reef elements within the September Lake reef complex define a series of vertical and horizontal superpositional relationships that are interpreted within a sequencestratigraphic framework (Figs. 8, 9). This regionally extensive, yet relatively thin, succession developed on a westwarddeepening platform during a major rise in relative sea level as a subtidal stromatolitic reef complex that shoaled to sea level and was that eventually overlain by peritidal stromatolites, pisoids, and evaporites of the upper member of the Sulky Formation (Kerans et al. 1981; Kerans and Donaldson 1988). The complex internal architecture of the September Lake reef complex, however, records the interaction between stromatolite growth and changes in accommodation space derived from both higher order changes in sea level and variation in the relief of the sea floor.

Reef growth initiated over at least four sea-level cycles (parasequence (PS)1-PS4, Fig. 9) that record progressive marine transgression across the Dismal Lakes platform. Stromatolite development during the first three sea-level cycles (PS1-PS3, Fig. 9) are laterally discontinuous and locally not all three parasequences are developed. This suggests that deposition occurred in topographic lows of variable depth that were created during pre-reef subaerial exposure and erosion of the underlying strata (SB1), and that individual rises in sea level may have been insufficient to flood the entire exposed platform. In all cases, however, the basal parasequence consists of irregular domal stromatolites interbedded with micrite, which transition upward into micrite-starved metre- 

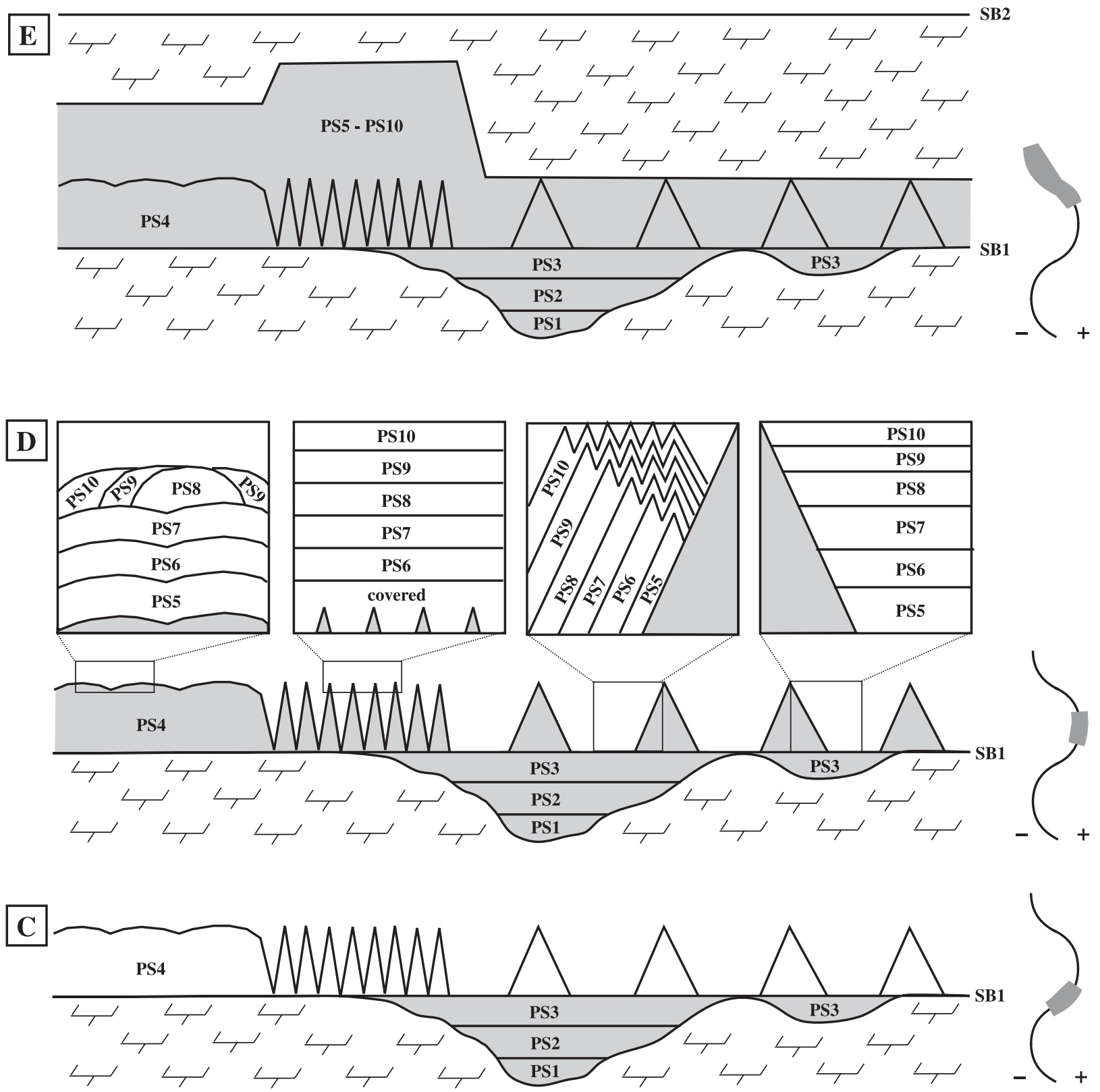

B
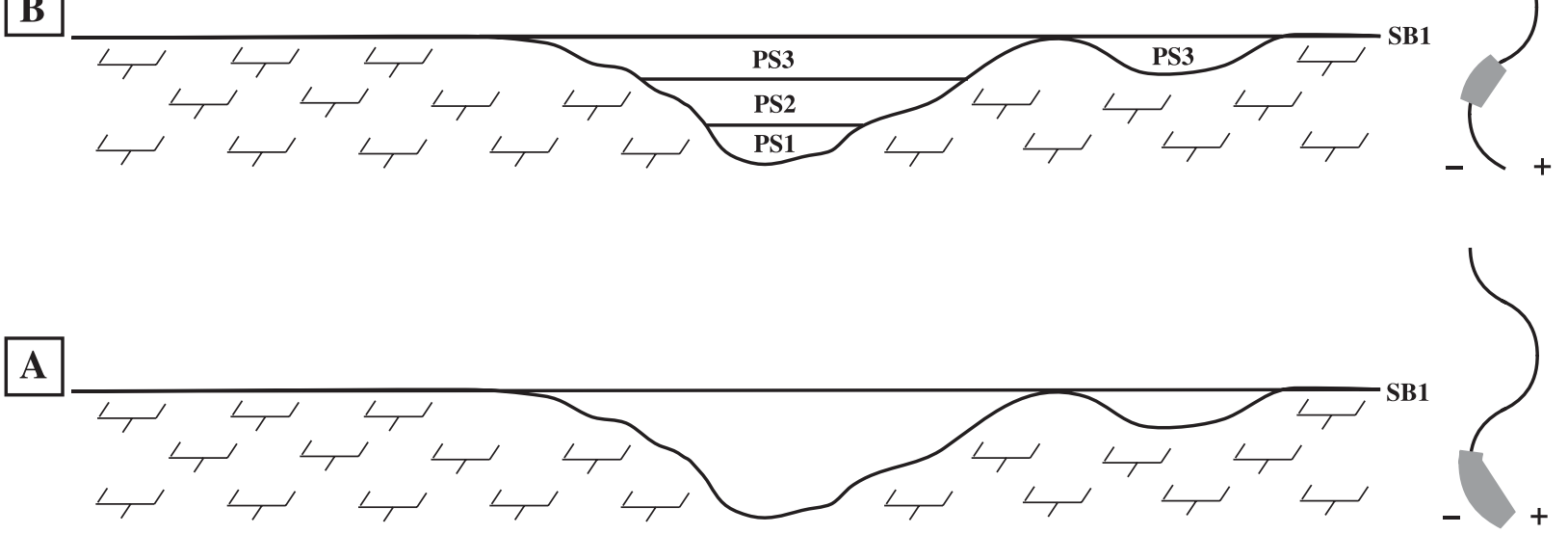
Fig. 9. Parasequence (PS) stacking during a major, 3rd-order sea-level cycle, with inferred sea-level position shown on right. (A) During sea-level lowstand, subaerial erosion of the September Lake high results in development of a type 1 sequence boundary (SB1), which truncates strata of the lower Sulky Formation. (B) Deposition of three, laterally discontinuous parasequences, PS1-PS3, marks early transgression. (C) Deep-water deposition of the 15 m thick PS4 marks the maximum transgression. Accretion of decametre-scale conical stromatolites likely continued into earliest highstand. (D) Highstand deposition results in shoaling of the reef complex by laterally variable stacking of PS5-PS10. (E) Across September Lake High, the reef complex is blanketed by cyclic packages of low domal to columnar stromatolites and fenestral to pisolitic dolostone that mark a return to peritidal depositional conditions during late highstand deposition. Subsequent lowstand deposition is marked by the deposition and subaerial exposure of a distinctive evaporite unit and by development of a regional type 2 sequence boundary (SB2).

scale cones that show an increase in synoptic relief in successive cycles, suggesting a decrease in both sediment influx and water energy associated with an increase in accommodation space during marine transgression. Where multiple parasequences are preserved, successive packages of conical stromatolites show both increasing diameter and synoptic relief, indicating an overall increase in accommodation space with successive sea-level cycles. In these initial parasequences, branching conical stromatolites of the form-genera Jacutophyton are developed only in the eastern part of the study region. The association of low synoptic relief branches with the erosion of conical laminae and the deposition of interstromatolitic debris suggests that development of Jacutophyton represents falling sea level that brought eastern portions of the platform to within fair-weather wave-base. In contrast, western portions of the reef are dominated by micrite-starved, non-branching cones, suggesting water depths that were great enough to remain beneath storm wave-base, even during falls in relative sea level. Greater accommodation space in the west likely resulted from a combination of the initial depositional dip along this westward-facing platform and greater subsidence in basinward regions of the platform.

The fourth sea-level cycle (PS4, Fig. 9) is represented by the widespread development of spectacular, decametre-scale coniform stromatolites and marks a dramatic increase in accommodation space and flooding of the entire September Lakes platform. The high synoptic relief of cones, absence of terrigenous deposition, and lack of evidence of erosional scour and reworking of debris into interstromatolitic regions supports the interpretation that giant cones were deposited beneath storm wave-base (Donaldson 1976), and suggests that PS4 represents a relative sea-level rise of at least several tens of metres. During deposition of PS4, variation in the spacing of adjacent stromatolites greatly affected the depositional profile of the reef. In the east, the wide spacing of adjacent cones resulted in local variation in reef topography of 10-13 m, whereas a westward decrease in the spacing between adjacent cones resulted in a progressive decrease in synoptic relief of the growth surface. The uniform thickness $(\sim 15 \mathrm{~m})$ of PS4, however, suggests similar rates of stromatolite accretion across the reef. Decametre-scale conical stromatolites of PS4 lack evidence of shoaling above wave-base, indicating that reef growth during PS4 was terminated by an abrupt decrease in relative sea level.

Variation in reef topography that was developed during PS4 played a primary role in the development of subsequent stromatolitic packages. In the west, where initial water depths were likely greatest, the decrease in accommodation space is marked by the preferential thickening of laminae at the interface between adjacent laterally linked cones, a gradual decrease in synoptic relief, and lowstand development of broad open domal stromatolite morphologies (Figs. 8A, 8B). A thin $(<15 \mathrm{~cm})$ red-stained, abraded, and crumbly interval at the top of broad domes indicates subaerial exposure of the outer reef tract at the end of PS4. The absence of obvious lowstand depositional packages between widely spaced cones suggests that the main reef core may also have been subaerially exposed at this time.

Eventual shoaling of the main reef complex occurs over an additional six or more sea-level cycles (PS5-PS10). In central to western regions of the study area, PS5-PS10 are variably represented by the successive stacking of conical and columnar stromatolite packages or by the lateral progradation of columnar stromatolite bioherms. The development of local $(<5 \mathrm{~km}$ along exposed outcrop) topographic variability within the outer reef tract during PS5-PS10 is indicated by (1) differences of up to $15 \mathrm{~m}$ in the thickness of the PS5-PS10 succession (Fig. 2), (2) an irregular distribution of shallower water (columnar) and deeper water (conical) stromatolite facies, (3) preservation of intrastromatolitic karst (Fig. 7) that indicates localized subaerial exposure of subtidal conical stromatolite facies, and (4) variation in aggradational versus progradational stacking patterns that reflect variability of local accommodation space.

In the east, stromatolite growth during PS5-PS10 effectively fills interstromatolitic regions of the reef core. These parasequences are represented either by the nucleation and growth of secondary conical stromatolites on the surfaces of large cones (Figs. 6C, 6D) or by the successive stacking of low, domal stromatolite packages that prograde outward from decametre-scale cones (Figs. 8C, 8D). The strongly progradational character of domal stromatolite packages suggests that upward growth of these forms may have been limited by available accommodation space; the stacked nature of these progradational elements represents nucleation and growth during successive rises in relative sea level. In contrast, the high synoptic relief of secondary conical stromatolites suggests that these stromatolites were not limited in their upward growth by available accommodation space. Development of individual parasequences are, instead, marked by nucleation of successive cone generations (Fig. 6D). Although additional detailed mapping is necessary to determine the spatial distribution of these different stromatolite growth morphologies, their close proximity also suggests the presence of local topographic variability of the substrate that is distinct from the synoptic relief developed during PS4.

By the end of PS10, much of the topographic relief on the reef appears to have been filled. Stromatolite growth during one or more additional sea-level cycles is represented by low-relief columnar to domal stromatolitic bioherms that blan- 
ket the reef core and mark the re-establishment of peritidal carbonate deposition in the upper Sulky member.

\section{Discussion}

\section{Extent and origin of changing sea level}

The September Lakes reef complex is similar to other well-documented, deep-water stromatolitic reefs, such as those the Mesoproterozoic Bylot Supergroup (Narbonne and James 1996) and Neoproterozoic Little Dal Group (Turner et al. 1997, 2000), in that it lacks any significant detrital sediment component; as a result, the primary factor in the development of reef geometries is the response of microbial growth to sea-level change and associated ecolic factors (cf. Wood 1999). The September Lake reef complex, however, varies dramatically from these other examples in both its aerial extent and stratigraphic thickness.

In the Coppermine homocline, the outcrop trace of the Sulky Formation suggests that reef development occurred over a region $>2400 \mathrm{~km}^{2}$ (Kerans and Donaldson 1988). The presence of an extraordinarily similar stromatolitic succession (high-relief conical stromatolites, with evidence of episodic exposure and subsequent growth of columnar and domal stromatolite forms) in the correlative Parry Bay Formation, Elu Basin (Campbell 1978, 1979; Kerans et al. 1981), which is $>300 \mathrm{~km}$ to the east of the Coppermine homocline, suggests that reef development might have extended for a minimum of $15000 \mathrm{~km}^{2}$ across the Laurentian craton. In this respect, the September Lake reef complex is more similar to the stromatolite reef complex exposed in late Mesoproterozoic (Teal et al. 2005) Atar Group, Mauritania (cf. Bertrand-Sarfati and Moussine-Pouchkine 1985, 1992; Moussine-Pouchkine and Bertrand-Sarfati 1997), whose outcrop trace suggests reef development over $\sim 10000 \mathrm{~km}^{2}$ in Mauritania and Algeria and which may have extended, during brief periods of high sea level, an additional lateral distance of $1500 \mathrm{~km}$ across the West African craton (Teal et al. 2005). Like the September Lake reef complex, the stromatolite reef complex in the Atar Group is also relatively thin $(<100 \mathrm{~m})$, composed largely of conical and branching conical stromatolites (Bertrand-Sarfati and Moussine-Pouchkine 1985), and contains several sequence boundaries that mark subaerial exposure of subtidal stromatolite facies (Kah and Bartley 2004).

The large aerial extent of these reef complexes suggests that the distribution of the reef growth was controlled primarily by the extent of marine flooding over broad cratonal regions. For the September Lake reef complex (and its correlative Nauyak reef complex, Parry Bay Group), an epicratonic setting is consistent with the region's paleogeographic position at the interface of the Laurentian and Siberian cratons within a pre-Rodinian cratonal core (Hoffman 1991; Condie and Rosen 1994; Rainbird et al. 1998) or even within a proximal pericratonic region, as required by reconstructions in which no cratonic segment is adjacent to the present-day northern margin of Laurentia (cf. Hartz and Torsvik 2002; Sears et al. 2004). In an epicratonic or proximal pericratonic setting, marine flooding may result from either changes in global eustatic sea level driven by changes in ocean volume via mid-ocean ridge spreading (Vail et al. 1991; Eriksson et al. 2005) or broad-scale subsidence driven by intraplate stresses resulting from regional extension or dynamic topography
(Cloetingh 1988; Miall 2005). Although seismic evidence suggests an episode of regional extension prior to deposition of the Dismal Lakes Group (Cook and MacLean 1992, 1995), the limited stratigraphic thickness of the September Lake reef complex and the sparse input of terrigenous detritus to the basin suggests minimal subsidence across the region and favors the preservation of a global eustatic signal flooding low-relief cratonal regions.

The magnitude of relative sea-level rise can be estimated by the thickness of the reef complex and by the inferred paleo-water depth of stromatolite deposition. In the September reef complex, transgression over pre-reef strata is recorded by PS1-PS4, with maximum flooding occurring during PS4. Parasequences PS1-PS3 record progressive marine transgression over exposed and excised strata of the lower Sulky Formation, during which up to $20 \mathrm{~m}$ of sedimentary strata was deposited. Parasequence PS4 represents the single largest component of relative sea-level rise. Stratal thicknesses up to $15 \mathrm{~m}$ are preserved in PS4, and it is inferred that the deposition of giant conical stromatolites during this time was restricted to beneath storm wave-base (conservatively $35-50 \mathrm{~m}$ ). These constraints suggest a conservative estimate placing cone tops no shallower than $35 \mathrm{~m}$, and would indicate a total rise in relative sea level of $70 \mathrm{~m}$ or more.

The origins of higher order (4th- or 5th-order, parasequencescale) sea-level changes are more difficult to interpret and probably reflect, at least in part, the influence of autocyclic processes (Vail et al. 1991; Miall 2005). In the case of the September Lake reef complex, incomplete shoaling of parasequences and evidence for subaerial exposure, particularly of subtidal coniform stromatolite facies, rules out autocyclicity as a primary mechanism behind parasequence formation and instead points to eustatic and (or) tectonic control. A strictly eustatic cause of relative sea-level changes cannot be ruled out in the absence of detailed geochronologic control that would indicate Milankovitch-scale processes. Basin-scale stratigraphic relationships and evidence of tectonic activity during depostion of the Dismal Lakes Group (Kerans 1983; Cook and MacLean 1996), however, suggests that the complex parasequence-scale cyclicity recorded in the September Lake reef complex may have resulted from a combination of eustatic processes and regional tectonic activity.

Kerans et al. (1981) suggested that reactivation of major basin fault systems may have ultimately controlled the basinward extent of the September Lake reef complex via development of the regional September Lake High. If this was the case, differential uplift and downdropping of fault blocks along the September Lake High may have controlled the differential excision of lower Sulky strata during development of the pre-reef unconformity. The uniform thickness and lateral continuity of PS4, however, suggests that variation in pre-reef topography was infilled by the end of PS3. We suggest, as well, that lateral variation in the character and total stratal thickness of PS5-PS10 is consistent with block faulting and tectonic dissection of the reef complex, which resulted in development of topographic irregularities across the reef top coincident with the fall in relative sea level at the end of PS4. Evidence for sea-level fall and exposure of reef elements in the correlative Nauyak reef complex, Parry Bay Formation, suggests that, unless uplift was extremely wide-ranging, it is unlikely that tectonic uplift and dissection of the northern 
Laurentian craton was wholly responsible for the post-PS4 sea-level fall. The uniform thickness and lateral continuity of peritidal parasequences of the post-reef upper Sulky member suggests, as well, that tectonic activity did not persist for an extended period of time and that any variation in reef topography was infilled during the broad-scale shoaling of the reef complex.

Determining the magnitude of sea-level rise recorded by higher order sea-level fluctuations is impeded by the hierarchical superposition with lower order transgressive events. During broad-scale transgressive events, it is periods of falling sea level in higher order cycles that can be most easily distinguished from the underlying signal. Several observations can be used to place estimates on the extent of sea-level fall. If conical stromatolites originally grew beneath storm wavebase, the extent of relative sea-level fall required for the simple termination of cone growth (cf. stacked non-branching metrescale cones of PS1-PS3) may be as little as a few metres. Our model for growth of Jacutophyton, in which branching records initial exposure of central cones to wave activity and growth of branches occurred within high-energy environments, suggests a relative sea-level fall of 20-40 m (i.e., the difference in water depth between storm and fair-weather wave-base). In cases where conical stromatolites are subaerially exposed at sea-level lowstand, the extent of sea-level fall would be estimated by adding the depth to storm wave-base to the synoptic relief of conical stromatolites, which could reach as great as 45-60 $\mathrm{m}$ in PS4.

Higher order (parasequence-scale) cyclicity in the September Lake reef may reflect short-lived, localized tectonic uplift of the September Lake region resulting from the pulsed emplacement of the Muskox intrusion, which has previously been implicated in both the pre-reef development of the September Lake High (Kerans et al. 1981) and development of a regional karst surface in the middle Greenhorn Formation (Kerans 1983). Careful sequence-stratigraphic correlation of reef parasequences with off-reef strata is necessary to more accurately determine the role played by intrabasinal tectonic uplift in the generation of high-amplitude, higher order changes in relative sea level.

\section{Summary and conclusions}

(1) Proterozoic reefs, like their Phanerozoic counterparts, are sensitive to sea-level change throughout their development. Whereas vertical stacking of expanding, contracting, or backstepping reef packages preserved a record of low-order (3rd-order) changes in relative sea level, the internal reef architecture of hierarchically packaged, individual reef elements preserves a record of higher order (4th- or 5th-order) changes in relative sea level.

(2) The middle member of the Sulky Formation, Dismal Lakes Group, arctic Canada, preserves a regionally extensive, yet relatively thin stromatolitic reef complex. The reef complex developed during a major marine transgression, shoaled to sea level and was overlain by peritidal carbonate strata. At least 10 higher order (i.e., parasequence scale) sea-level cycles are recognized; PS1-PS4 mark the progressive flooding of the sub-reef platform, PS4 represents the main phase of reef growth, and PS5PS10 record the gradual shoaling of the reef system.
(3) Lateral variation in the internal reef architecture records the interaction among changing accommodation space, variation in the bathymetry of the sea floor driven by stromatolite growth, potentially higher rates of subsidence in basinward regions of the reef complex, and episodic tectonic dissection and variable uplift of the reef top.

(4) The extent of relative sea-level change throughout development of the September Lake reef complex is estimated from models of stromatolite growth. Ultimately, reef growth requires a rise in sea level of $70 \mathrm{~m}$ or more for reef growth, and amplitudes of higher order sea-level fluctuations between $\sim 20$ and $60 \mathrm{~m}$. Higher order sealevel changes likely reflect a combination of eustatic and tectonic forcing.

\section{Acknowledgments}

Field work was supported in 1998 by National Science Foundation grants EAR-9725536 (to T.W. Lyons and L.C. Kah) and EAR-9725395 (to T.D. Frank) and in 2002 by the University of Tennessee's Office of Research and Provost's Professional Development funds (to L.C. Kah). Canada's Department of Indian and Northern Affairs, Department of Wildlife and Fisheries, Air Tindi, and Doug Smith (Stornoway Ventures) are acknowledged for logistical support; Karla Cairns (Indian and Northern Affairs Canada) for expediting our 2002 season; and B. Thomas, M. Formolo, B. McInnish, and P. Schuneman for field assistance. Thoughtful reviews by B.R. Pratt and P.-A. Bourque helped to improve the clarity of the manuscript.

\section{References}

Aitken, J., and Pugh, D. 1984. The Fort Norman and Leith Ridge structures: major, buried, Precambrian features underlying Franklin Mountains and Great Bear and Mackenzie Plains. Bulletin of Canadian Petroleum Geology, 32: 139-146.

Anderson, H.E., and Davis, D.W. 1995. U-Pb geochronology of the Moyie sills, Purcell Supergroup, southeastern British Columbia: implications for the Mesoproterozoic geological history of the Purcell (Belt) basin. Canadian Journal of Earth Sciences, 32: 1180-1193.

Barager, W.R.A., and Donaldson, J.A. 1973. Coppermine and Dismal Lakes Map Area. Geological Survey of Canada, Paper 71-39, pp 1-20.

Bertrand-Sarfati, J., and Moussine-Pouchkine, A. 1985. Evolutionary and environmental conditions of Conophyton-Jacutophyton associations in the Atar Dolomite (Upper Proterozoic, Mauritania). Precambrian Research, 29: 207-234.

Bertrand-Sarfati, J., and Moussine-Pouchkine, A. 1992. Formation et comblement d'une dépression intraplateforme engendreé par la croissance d'un biostrome stromatolitique, Protérozoïque supérieur, Sahara algérien. Compte-Rendus de l'Académie des Sciences, Paris, 315: 837-843.

Beukes, N.J. 1987. Facies relations, depositional environments and diagenesis in a major early Proterozoic stromatolitic carbonate platform to basinal sequence. Campbellrand Subgroup, Transvaal Supergroup, southern Africa. Sedimentary Geology, 54: 1-46.

Bowring, S.A., and Ross, G.M. 1985. Geochronology of the Narakay volcanic complex: Implications for the age of the Coppermine Homocline and Mackenzie igneous events. Canadian Journal of Earth Sciences, 22: 774-780.

Campbell, F.H.A. 1978. Geology of the Helikian rocks of the Bathurst 
Inlet area, Northwest Territories. Geological Survey of Canada, Paper 78-1A, pp. 97-106.

Campbell, F.H.A. 1979. Stratigraphy and sedimentation in the Helikian Elu Basin and Hiukitak Platform, Bathurst-Inlet-Melville Sound, Northwest Territories. Geological Survey of Canada, Paper 79-8, pp. 1-18.

Cloetingh, S. 1988. Intraplate stress: a tectonic cause for thirdorder cycles in apparent sea level. In Sea-level changes-an integrated approach. Edited by C.K. Wilgus, B.S. Hastings, C.G.St.C. Kendall, H.W. Posamentier, C.A.Ross, and J.C. Van Wagoner. Soeciety of Economic Paleontologists and Mineralogists, Special Publication 42, pp. 19-30.

Condie, K.C., and Rosen, O.M. 1994. Laurentia-Siberia connection revisited. Geology, 22: 168-170.

Cook, D.G., and MacLean, B.C. 1992. Proterozoic thick-skinned intracratonic deformation, Colville Hills region, Northwest Territories, Canada. Geology, 20: 67-70.

Cook, D.G., and MacLean, B.C. 1995. The intracratonic Palaeoproterozoic Forward orogeny, and implications for regional correlations, Northwest Territories, Canada. Canadian Journal of Earth Sciences, 32: 1991-2008.

Cook, D.G., and MacLean, B.C. 1996. Mid-continent tectonic inversions, Northwest Territories, Canada. Journal of Structural Geology, 18: 791-802.

Cook, F.A., and Taylor, G.G. 1991. Seismic reflection trace synthesized from Proterozoic outcrop and its correlation to seismic profiles in northwestern Canada. Tectonophysics, 191: 111-126.

de Wet, C.B., Dickson, J.A.D., Wood, R.A., Gasworth, S.B., and Frey, H.M. 1999. A new type of shelf margin deposit: rigid microbial sheets and unconsolidated grainstones riddled with metre-scale cavities. Sedimentary Geology, 128: 13-21.

Donaldson, J.A. 1976. Palaeoecology of conophyton and associated stromatolites in the Precambrian Dismal Lakes and Rae groups, Canada. In Stromatolites. Edited by M.R. Walter. Elsevier, Amsterdam, The Netherlands, pp. 523-534.

Doughty, P.T., and Chamberlain, K.R. 1996. Salmon River Arch revisited: New evidence for 1370 Ma rifting near the end of deposition in the Middle Proterozoic Belt basin. Canadian Journal of Earth Sciences, 33: 1037-1052.

Emery, D., and Myers, K. 1996. Sequence stratigraphy. Blackwell, Oxford, UK.

Eriksson, P.G., Catuneanu, O., Nelson, D.R., and Popa, M. 2005. Controls on Precambrian sea level change and sedimentary cyclicity. Sedimentary Geology, 176: 43-65.

Frank, T.D., Kah, L.C., and Lyons, T.W. 2003. Changes in organic matter production and accumulation as a mechanism for isotopic evolution in the Mesoproterozoic ocean. Geological Magazine, 140: $397-420$.

Grotzinger, J.P. 1986. Upward-shallowing platform cycles: a response to 2.2 billion years of low-amplitude, high frequency (Milankovitch band) sea level oscillation. Paleoceanography, 1: 403-416.

Grotzinger, J.P. 1989. Construction of Early Proterozoic (1.9Ga) barrier reef complex, Rocknest platform, Northwest Territories. In Reefs, Canada and adjacent areas. Edited by H.H.J. Geldsetzer, N.P. James, and G.E. Tebbutt. Canadian Society of Petroleum Geologists, Memoir 13, pp. 30-37.

Grozinger, J.P., and Knoll, A.H. 1999. Stromatolites in Precambrian carbonates: Evolutionary mileposts or environmental dipsticks? Annual Reviews of Earth and Planetary Sciences, 27: 313-358.

Hartz, E.H., and Torsvik, T.H. 2002. Baltica upside down: a new plate tectonic model for Rodinia and Iapetus Ocean. Geology, 30: $255-258$.
Hildebrand, R. 1981. Early Proterozoic Labine Group of Wopmay Orogen: remnant of a continental volcanic arc developed during oblique convergence. In Proterozoic basins of Canada. Edited by F.H.A. Campbell. Geological Survey of Canada, Paper 81-10, pp. 133-56.

Hoffman, P.F. 1967. Algal stromatolites: use in stratigraphic correlation and paleocurrent determination. Science, 157: 1043-1045.

Hoffman, P.F. 1976. Environmental diversity of Middle Precambrian stromatolites. In Stromatolites. Edited by M.R. Walter. Elsevier, Amsterdam, The Netherlands, pp. 599-611.

Hoffman, P.F. 1991. Did the breakout of Laurentia turn Gondwanaland inside-out? Science, 252: 1409-1412.

Hoffman, P.F., and Bowring, S.A. 1984. Short-lived 1.9 Ga continental margin and its destruction, Wopmay orogen, northwest Canada. Geology, 12: 68-72.

James, N.P., and Bourque, P.-A. 1992. Reefs and mounds. In Facies models: response to sea level change. Edited by R.G.Walker and N.P. James. Geological Association of Canada, pp. 323-347.

Kah, L.C., and Bartley, J.K. 2004. Growth dynamics of stromatolite reefs in the Mesoproterozoic Atar Group, Mauritania. Geological Society of America, Abstracts with Programs, Southeast Section, 36: 111A.

Kah, L.C., Bartley, J.K., Frank, T.D., and Lyons, T.W. 1999. Reef facies and possible chemosynthetic communities of the Sulky formation, 1.3 Ga Dismal Lakes Group, N.W.T., Canada. Geological Association of Canada - Mineralogical Association of Canada, Joint Annual Meeting Abstracts, 24: 60A.

Kerans, C. 1983. Timing of emplacement of the Muskox intrusions: constraints from Coppermine Homocline cover strata. Canadian Journal of Earth Sciences, 20: 673-683.

Kerans, C., and Donaldson, J.A. 1988. Proterozoic palaeokarst profile, Dismal Lakes Group, N.W.T., Canada. In Palaeokarst. Edited by N.P. James and P.W. Choquette. Springer-Verlag, New York, N.Y., pp. 167-182.

Kerans, C., and Donaldson, J.A. 1989. Deepwater conical stromatolite reef, Sulky Formation (Dismal Lakes Group), Middle Proterozoic, N.W.T. In Reefs, Canada and adjacent areas. Edited by H.H.J. Geldsetzer, N.P. James, and G.E. Tebbutt. Canadian Society of Petroleum Geologists, Memoir 13, pp. 81-88.

Kerans, C., Ross, G.M., Donaldson, J.A., and Geldsetzer, H.J. 1981. Tectonism and depositional history of the Helikian Hornby Bay and Dismal Lakes groups, District of Mackenzie. In Proterozoic basins of Canada. Edited by F.H.A. Campbell. Geological Survey of Canada, Paper 81-10, pp. 157-182.

Kiessling, W. 2002. Secular variations in the Phanerozoic reef ecosystem. In Phanerozoic reef patterns. Edited by W. Kiessling, E. Fluegel, and J. Golonka. Society for Sedimentary Geology, Special Publication 72, pp. 625-690.

LeCheminant, A.N., and Heaman, L.M. 1989. Mackenzie igneous events, Canada: Middle Proterozoic hotspot magmatism associated with ocean opening. Earth and Planetary Science Letters, 96: 38-48.

Lemon, N.M. 2000. A Neoproterozoic fringing stromatolite reef complex, Finders Ranges, South Australia. Precambrian Research, 100: $109-120$.

Miall, A.D. 1997. The geology of stratigraphic sequences. SpringerVerlag, Berlin, Germany.

Miall, A.D. 2005. Testing for eustatic sea-level control in the Precambrian sedimentary record. Sedimentary Geology, 176: 9-16.

Moussine-Pouchkine, A., and Bertrand-Sarfati, J. 1997. Tectonosedimentary subdivisions on the Neoproterozoic cover of the Taoudenni basin (Algeria, Mauritania, Mali). Journal of African Earth Sciences, 25: 425-443.

Narbonne, G.M., and James, N.P. 1996. Mesoproterozoic deep- 
water reefs from Borden Peninsula, Arctic Canada. Sedimentology, 43: 827-848.

Parrish, R.R., and Bell, R.T. 1987. Age of the NOR Breccia Pipe, Wernecke Supergroup, radiogenic age and isotopic studies. Geological Survey of Canada, Paper 87-2, pp. 3-42.

Pelechaty, S.M., James, N.P., Kerans, C., and Grotzinger, J.P. 1991. A middle Proterozoic palaeokarst unconformity and associated sedimentary rocks; Elu Basin, Northwest Canada. Sedimentology, 38: 775-797.

Rainbird, R.H., Jefferson, C.W., and Young, G.M. 1996. The early Neoproterozoic sedimentary Succession B of northwestern Laurentia: Correlations and palaeogeographic significance. Geological Society of America Bulletin, 108: 454-470.

Rainbird, R.H., Stern, R.A., Khudoley, A.K., Kropachev, A.P., Heaman, L.M., and Sukhorukov, V.I. 1998. U-Pb geochronology of Riphean sandstone and gabbro from southeast Siberia and its bearing on the Laurentia-Siberia connection. Earth and Planetary Science Letters, 164: 409-420.

Ross, G.M. 1982. The Narakay Volcanic Complex: mafic volcanism in the Helikian Hornby Bay Group of Dease Arm, Great Bear Lake-a preliminary report on depositional processes and tectonic significance. Geological Survey of Canada, Paper 82-1A, pp. 329-340.

Ross, G.M., and Kerans, C. 1988. Geology of the Hornby Bay and Dismal Lakes groups, Coppermine Homocline, District of Mackenzie, Northwest Territories. Geological Survey of Canada, Map 1663A, scale 1: 250000.

Sears, J.W., Price, R.A., and Khudoley, A.K. 2004. Linking the Mesoproterozoic Belt-Purcell and Udzha basins across west Laurentia-Siberia connection. Precambrian Research, 129: 291-308.

Semikhatov, M.A., Gebelein, C.D., Cloud, P., Awramik, S.M., and
Benmore, W.C. 1979. Stromatolite morphogenesis—progress and problems. Canadian Journal of Earth Sciences, 19: 992-1015.

Sumner, D.Y., and Grotzinger, J.P. 1996a. Herringbone calcite: petrography and environmental significance. Journal of Sedimentary Research, 66: 419-429.

Sumner, D.Y., and Grotzinger, J.P. 1996b. Were kinetics of Archean calcium carbonate precipitation related to oxygen concentration? Geology, 24: 119-122.

Teal, D.A., Jr., Kah, L.C., and Bartley, J.K. 2005. Using C-isotopes to constrain intrabasinal stratigraphic correlations: Mesoproterozoic Atar Group, Mauritania. Geological Society of America, Abstracts with Programs, Southeast Section, 37: 45A.

Tourre, S.A., and Sumner, D.Y. 2000. Geochemistry of herringbone calcite from an ancient Egyptian quarry. Geological Society of America, Abstracts with Programs, 32: 215A.

Turner, E.C., James, N.P., and Narbonne, G.M. 1997. Growth dynamics of Neoproterozoic calcimicrobial reefs, Mackenzie Mountains, northwest Canada: Journal of Sedimentary Research, 67: 437-450.

Turner, E.C., Narbonne, G.M., and James, N.P., 2000. Framework composition of early Neoproterozoic calcimicrobial reefs and associated microbialites, Mackenzie Mountains, N.W.T., Canada. In Carbonate sedimentation and diagenesis in the evolving Precambrian world. Edited by J.P. Grotzinger and N.P. James. Society for Sedimentary Geology, Special Publication 67, pp. 181-205.

Vail, P.R., Audemart, F., Bowman, S.A., Eisner, P.N., and PerezCruz, G. 1991. The stratigraphic signatures of tectonics, eustasy, and sedimentation-an overview. In Cyclic stratigraphy. Edited by G. Einsele, W. Ricken, and A. Seilacher. Springer-Verlag, New York, N.Y., pp. 617-659.

Wood, R.A. 1999. Reef evolution. Oxford University Press, Oxford, UK. 